\title{
Evaluation of a three-dimensional chemical transport model (PMCAMx) in the European domain during the EUCAARI May 2008 campaign
}

\author{
C. Fountoukis ${ }^{1}$, P. N. Racherla ${ }^{2}$, H. A. C. Denier van der Gon ${ }^{3}$, P. Polymeneas ${ }^{4}$, P. E. Charalampidis ${ }^{4}$, C. Pilinis ${ }^{4}$, \\ A. Wiedensohler ${ }^{5}$, M. Dall'Osto ${ }^{6}$, C. O'Dowd ${ }^{6, *}$, and S. N. Pandis ${ }^{1,7,8}$ \\ ${ }^{1}$ Institute of Chemical Engineering and High Temperature Chemical Processes, Foundation for Research and Technology \\ Hellas (FORTH), Patras, Greece \\ ${ }^{2}$ NASA Goddard Institute for Space Studies, New York, NY 10025, USA \\ ${ }^{3}$ TNO Built Environment and Geosciences, Princetonlaan 6, 3584 CB Utrecht, The Netherlands \\ ${ }^{4}$ Department of Environment, University of the Aegean, University Hill, 81100, Mytilene, Greece \\ ${ }^{5}$ Leibniz Institute for Tropospheric Research, 04318 Leipzig, Germany \\ ${ }^{6}$ School of Physics and Centre for Climate \& Air Pollution Studies, National University of Ireland Galway, University Road, \\ Galway, Ireland \\ ${ }^{7}$ Department of Chemical Engineering, University of Patras, Patras, Greece \\ ${ }^{8}$ Department of Chemical Engineering, Carnegie Mellon University, Pittsburgh, PA 15213, USA \\ "now at: Institute for Environmental Assessment and Water Research (IDA-CSIC), Barcelona, Spain
}

Received: 23 March 2011 - Published in Atmos. Chem. Phys. Discuss.: 9 May 2011

Revised: 24 September 2011 - Accepted: 27 September 2011 - Published: 18 October 2011

\begin{abstract}
PMCAMx-2008, a detailed three-dimensional chemical transport model (CTM), was applied to Europe to simulate the mass concentration and chemical composition of particulate matter (PM) during May 2008. The model includes a state-of-the-art organic aerosol module which is based on the volatility basis set framework treating both primary and secondary organic components as semivolatile and photochemically reactive. The model performance is evaluated against high time resolution aerosol mass spectrometer (AMS) ground and airborne measurements. Overall, organic aerosol is predicted to account for $32 \%$ of total $\mathrm{PM}_{1}$ at ground level during May 2008, followed by sulfate (30\%), crustal material and sea-salt (14\%), ammonium (13\%), nitrate $(7 \%)$, and elemental carbon $(4 \%)$. The model predicts that fresh primary OA (POA) is a small contributor to organic PM concentrations in Europe during late spring, and that oxygenated species (oxidized primary and biogenic secondary) dominate the ambient OA. The Mediterranean region is the only area in Europe where sulfate concentrations are predicted to be much higher than the OA, while organic matter is predicted to be the dominant $\mathrm{PM}_{1}$ species in cen-
\end{abstract}

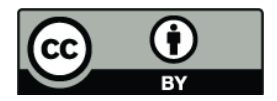

Correspondence to: S. N. Pandis (spyros@andrew.cmu.edu) tral and northern Europe. The comparison of the model predictions with the ground measurements in four measurement stations is encouraging. The model reproduces more than $94 \%$ of the daily averaged data and more than $87 \%$ of the hourly data within a factor of 2 for $\mathrm{PM}_{1} \mathrm{OA}$. The model tends to predict relatively flat diurnal profiles for $\mathrm{PM}_{1} \mathrm{OA}$ in many areas, both rural and urban in agreement with the available measurements. The model performance against the high time resolution airborne measurements at multiple altitudes and locations is as good as its performance against the ground level hourly measurements. There is no evidence of missing sources of OA aloft over Europe during this period.

\section{Introduction}

Fine particulate matter is a prime contributor to various air quality problems such as visibility reduction (Seinfeld and Pandis, 2006), public health (Pope et al., 2002), formation of acid rain (Burtraw et al., 2007) and climate change (Schwartz, 1996). Atmospheric aerosols are mainly comprised of water, inorganic salts, organics, and trace elements. A large part of the particulate mass is often inorganic, with sulfate, ammonium, nitrate, sodium and chloride

Published by Copernicus Publications on behalf of the European Geosciences Union. 
being usually the dominant species. Ammonium and sulfate are usually present in the fine mode (particles with diameters less than $1 \mu \mathrm{m}$ ), nitrate can be found in both the fine and coarse (particles with diameters larger than $1 \mu \mathrm{m}$ ) modes, while sodium and chloride are mainly found in the coarse mode (Seinfeld and Pandis, 2006). Sulfate and organics are the major components of sub-micrometer particles $\left(\mathrm{PM}_{1}\right)$ in most locations throughout the world. Organic particulate matter, originating from many different natural and anthropogenic sources and processes, is the least understood component of atmospheric aerosols. More than $50 \%$ of the atmospheric fine aerosol mass can be comprised of organic compounds at continental mid-latitudes and as high as $90 \%$ in tropical forested areas (Andreae and Crutzen, 1997; Roberts et al., 2001; Kanakidou et al., 2005).

Organic aerosol (OA) is generally categorized into two types; primary organic aerosol (POA) which is injected into the atmosphere in the particulate phase and secondary organic aerosol (SOA) which is formed from volatile organic compounds (VOCs) in the gas phase that react and condense in the particulate phase. Within the last decade, several new methods have emerged that can analyze and quantify the different types of OA present in ambient aerosol. Among several measurement techniques, the Aerosol Mass Spectrometer (AMS) is the most commonly used to measure the size-resolved mass concentration and corresponding total mass spectrum of organic aerosols with a time resolution of minutes (Jayne et al., 2000; Jimenez et al., 2003; Zhang et al., 2005a; Takegawa et al., 2005). Based on the AMS measurements, one can classify OA into two types based on their different temporal and mass spectral signatures; the hydrocarbon-like organic aerosol (HOA) and the oxygenated organic aerosol (OOA) which together usually account for most of the OA mass measured by the AMS (Zhang et al., 2005b).

Gelencser et al. (2007) studied the sources of organic $\mathrm{PM}_{2.5}$ aerosol in five rural/remote sites in Europe combining radiocarbon measurements with bulk measurements of organic carbon, elemental carbon, and two organic tracers. They found that biomass burning and fossil fuel combustion were the main sources in winter, while secondary SOA from non-fossil sources was the dominant contributor (63$76 \%$ of total carbon in $\mathrm{PM}_{2.5}$ ) during the summer followed by SOA from fossil fuel combustion. Szidat et al. (2006) quantified the contributions of fossil fuel, biomass-burning, and biogenic emissions to carbonaceous $\mathrm{PM}_{10}$ aerosols in Zurich based on ${ }^{14} \mathrm{C}$ measurements and reported that biogenic sources dominated in the summer $(60 \%)$ and wood combustion in the winter (around $40 \%$ of OA) while fossil fuel combustion accounted for $30 \%$ of the OA throughout the year. Tunved et al. (2006) showed a clear relationship between accumulated terpene emissions and particle mass changes over the European Boreal region, suggesting that in clean air conditions the buildup of PM is due largely to the oxidation of biogenic precursors.
In order to better understand the role of organic aerosol, regional and global air quality and climate models need to be able to correctly predict the concentrations of these different types of OA. Earlier OA modeling studies in Europe (Andersson-Skold and Simpson, 2001; Schell et al., 2001; Tsigaridis and Kanakidou, 2003) have suggested that biogenic SOA is the major source of OA in many parts of Europe; however measurement data for the evaluation of these predictions was scarce. Simpson et al. (2007) predicted using the EMEP model that the contribution of biogenic SOA (bSOA) far exceeds that of anthropogenic SOA (aSOA) while the relative contribution of bSOA compared to POA varies significantly across Europe and at different times of the year. Bessagnet et al. (2008) compared predictions of the CHIMERE CTM with filter measurements during 2003, emphasizing the importance of isoprene chemistry on SOA formation. CTMs have traditionally treated POA as non-volatile and non-reactive and SOA as semi-volatile products of VOC oxidation (Kanakidou et al., 2005). Several recent studies have shown that POA is semi-volatile (Lipsky and Robinson, 2006; Robinson et al., 2007; Huffman et al., 2009a, b) while SOA can be seriously underpredicted by models that use traditional SOA precursors and do not take into account further oxidation of these compounds (Baltensperger et al., 2005; Ng et al., 2006; Hildebrandt et al., 2009; Dzepina et al., 2009). Lane et al. (2008a, b) implemented the volatility basis set framework (Donahue et al., 2006; Stanier et al., 2008) in PMCAMx for the SOA components using four surrogate species with saturation concentrations of $1,10,100$, and $1000 \mu \mathrm{g} \mathrm{m}^{-3}$ at $298 \mathrm{~K}$, and employed a chemical aging mechanism which shifts mass down by one volatility bin during gas-phase reactions of the corresponding surrogate species with OH. Shrivastava et al. (2008), using the CTM PMCAMx, reassigned the nonvolatile POA to volatility bins and incorporated the chemical aging of the gas-phase POA by assuming reaction with the hydroxyl radical $\mathrm{OH}$, thus treating POA as semi-volatile and reactive. The above two approaches for POA and SOA were combined in a single CTM (PMCAMx-2008) (Murphy and Pandis, 2009; Tsimpidi et al., 2010; Karydis et al., 2010). Tsimpidi et al. (2010) applied PMCAMx-2008 to the polluted area of Mexico City during April 2003 and March 2006. The model reproduced well the AMS measurements of HOA and OOA. Murphy and Pandis (2009) applied PMCAMx-2008 in the Eastern United States and evaluated the new modeling framework against daily ambient measurements from the EPA STN (Speciated Trends Network) and the IMPROVE (Interagency Monitoring of Protected Visual Environments) data as well as hourly data from PAQS (Pittsburgh Air Quality Study). Unfortunately, AMS data were not available for the evaluation of the predictions of the model.

In this work PMCAMx-2008 is applied for the first time in the European domain to simulate the chemical composition and mass of the major $\mathrm{PM}_{1}$ components during the month of May 2008 during which an intensive campaign 
of measurements was performed in Europe as part of the European Aerosol Cloud Climate and Air Quality Interactions project (Kulmala et al., 2009). The model performance is evaluated against hourly averaged AMS ground measurements as well as airborne measurements from an aircraft field campaign over Europe (Morgan et al., 2010b).

\section{PMCAMx-2008 description}

PMCAMx-2008 (Murphy and Pandis, 2009; Tsimpidi et al., 2010; Karydis et al., 2010) uses the framework of the CAMx air quality model (Environ, 2003) describing the processes of horizontal and vertical advection, horizontal and vertical dispersion, wet and dry deposition, and gas-phase chemistry. For wet deposition PMCAMx uses a scavenging coefficient approach, in which the local rate of concentration change within or below a precipitating cloud is equal to the product of the concentration of a pollutant and the corresponding scavenging coefficient. The scavenging coefficient is determined differently for gases and particles, based upon relationships described by Seinfeld and Pandis (2006). For dry deposition, PMCAMx determines a deposition velocity for each land use type, for each given species, particle size, and grid cell, and then linearly combines them according to the fractional distribution of land use in the cell. The deposition flux is used as the lower boundary condition in the vertical diffusion algorithm. For the gas phase species, the resistance model of Wesely (1989) is used, while for aerosol the resistance approach of Slinn and Slinn (1980), as implemented in UAM-AERO (Kumar et al., 1996), has been adopted in PMCAMx. An effective Henry's Law constant, which affects vapor removal processes, of $2700 \mathrm{M} \mathrm{atm}^{-1}$ is used for all gas-phase OA species (Murphy and Pandis, 2009). For the aerosol processes, three detailed aerosol modules are used. The approach of Fahey and Pandis (2001) is used for the simulation of aqueous-phase chemistry. The inorganic aerosol growth is described in Gaydos et al. (2003) and Koo et al. (2003), and the secondary organic aerosol (SOA) formation and growth in Koo et al. (2003). These aerosol modules use a sectional approach to dynamically track the size evolution of the aerosol mass across 10 size sections spanning from $40 \mathrm{~nm}$ to $40 \mu \mathrm{m}$. The aerosol species modeled include sulfate, nitrate, ammonium, sodium, chloride, potassium, calcium, magnesium, elemental carbon, primary and secondary organics. The chemical mechanism used in the gas-phase chemistry is based on the SAPRC99 mechanism (Carter, 2000; Environ, 2003). The version of SAPRC99 used here includes 211 reactions of 56 gases and 18 radicals and has five lumped alkanes, two olefins, two aromatics, isoprene, a lumped monoterpene species, and a lumped sesquiterpene species.
Three options are available in PMCAMx-2008 for the simulation of inorganic aerosol growth. The most computationally efficient approach is the bulk equilibrium approach, which assumes equilibrium between the bulk inorganic aerosol and gas phase. At a given time step the amount of each species transferred between the gas and aerosol phases is determined by applying the aerosol thermodynamic equilibrium model ISORROPIA (Nenes et al., 1998) and is then distributed over the aerosol size sections by using weighting factors for each size section based on their surface area (Pandis et al., 1993). The second approach (hybrid approach) assumes equilibrium for the fine particles $(<1 \mu \mathrm{m})$ and solves the mass transfer differential equations for the coarse particles (Capaldo et al., 2000). The most accurate but computationally demanding method is the dynamic approach where mass transfer is simulated explicitly for all particles (Pilinis et al., 2000). In this work we use the bulk equilibrium approach since we are focusing on the model's performance for fine particles.

Based on the approach of Shrivastava et al. (2008), primary organic aerosol in PMCAMx-2008 is assumed to be semivolatile. Nine surrogate POA species are used, with effective saturation concentrations at $298 \mathrm{~K}$ ranging from $10^{-2}$ to $10^{6} \mu \mathrm{g} \mathrm{m}^{-3}$. POA is simulated in the model in two types, "fresh" (unoxidized) POA and oxidized POA (OPOA). For the intermediate VOC (IVOC) emissions we followed the approach of Tsimpidi et al. (2010) and Shrivastava et al. (2008), in which the IVOC emissions are proportional to the emitted primary OA mass. Emission inventories do not include these compounds because of the difficulty in measuring mass in this volatility range (it is emitted and remains largely in the gas phase), and thus we add an additional 1.5 times the original POA mass emission rate to the intermediate volatility organic gas emission rate following several past studies (Robinson et al., 2007; Murphy and Pandis, 2009; Hodzic et al., 2010; Tsimpidi et al., 2010). In the gas phase, this mass can be oxidized by $\mathrm{OH}$ and may go to lower volatility and condense. SOA consists of organic aerosol of anthropogenic (aSOA) and biogenic (bSOA) origin. The SOA volatility basis-set approach (Lane et al., 2008a) used in the current version of the model includes four SOA species for each VOC with 4 volatility bins $\left(1,10,100,1000 \mu \mathrm{g} \mathrm{m}^{-3}\right)$. Laboratory results from recent smog-chamber experiments (Ng et al., 2006; Hildebrandt et al., 2009) have been used to update the SOA module in PMCAMx in order to include anthropogenic aerosol yields. The SOA module incorporates $\mathrm{NO}_{\mathrm{x}}$-dependent $\mathrm{SOA}$ yields (Lane et al., 2008b) which are based on an assumed density of $1.5 \mathrm{~g} \mathrm{~cm}^{-3}$. The model treats all organic species (primary and secondary) as chemically reactive. Chemical aging through gas-phase oxidation of OA vapors is modeled using a gas-phase $\mathrm{OH}$ reaction with a rate constant of $k=1 \times 10^{-11} \mathrm{~cm}^{3} \mathrm{molec}^{-1} \mathrm{~s}^{-1}$ for anthropogenic SOA and $k=4 \times 10^{-11} \mathrm{~cm}^{3} \mathrm{molec}^{-1} \mathrm{~s}^{-1}$ for the primary OA (Atkinson and Arey, 2003). Each reaction is assumed to decrease the volatility of the vapor material by a 
factor of 10. The base-case simulation neglects the chemical aging of biogenic SOA. It effectively assumes that the chemical aging reactions of biogenic SOA (leading to both functionalization and fragmentation) do not result in a net increase of the bSOA concentration.

\section{Model application}

During May 2008 an intensive campaign of measurements was performed in Europe as part of the European Aerosol Cloud Climate and Air Quality Interactions (EUCAARI) project (Kulmala et al., 2009). The campaign included both ground measurements at various European measurement stations as well as airborne measurements in North-Western Europe. The PMCAMx-2008 modeling domain covers a $5400 \times 5832 \mathrm{~km}^{2}$ region in Europe with $36 \times 36 \mathrm{~km}$ grid resolution and 14 vertical layers covering approximately $6 \mathrm{~km}$ (Fig. 1). PMCAMx-2008 was set to perform simulations on a rotated polar stereographic map projection. The first two days of each simulation were excluded from the analysis to limit the effect of the initial conditions on the results. Concentrations of the major $\mathrm{PM}_{1}$ species at the boundaries of the domain (Table 1) are based on measured average background concentrations in sites close to the boundaries of the domain (e.g. Zhang et al., 2007; Seinfeld and Pandis 2006). The boundary condition organic aerosol (BC-OA) is expected to consist of both SOA and oxidized POA. Here we assume that the BC-OA is all oxidized and half of it is biogenic OA and the other half oxidized primary OA (Kanakidou et al., 2005; Farina et al., 2010). All concentrations reported here are under ambient temperature and pressure conditions.

The necessary inputs to the model include horizontal wind components, vertical diffusivity, temperature, pressure, water vapor, clouds and rainfall. The meteorological model WRF (Weather Research and Forecasting) (Skamarock et al., 2005) was used to create the above inputs. WRF was driven by static geographical data and dynamic meteorological data (near real-time and historical data generated by the Global Forecast System $\left.\left(1 \times 1^{\circ}\right)\right)$. 27 sigma-p layers up to 0.1 bars were used in the vertical dimension. Each layer of PMCAMx-2008 is aligned with the layers used in WRF. The WRF May 2008 run was periodically (every 3 days) reinitialized to ensure accuracy in the corresponding fields that are used as inputs in PMCAMx-2008.

Anthropogenic and biogenic hourly emission gridded fields were developed for the European domain for gases and primary particulate matter. Volatile organic compounds are split based on the speciation approach proposed by Visschedijk et al. (2007). Anthropogenic gas emissions that were used to develop the gridded fields include land emissions from the GEMS dataset (Visschedijk et al., 2007) as well as international shipping emissions. Anthropogenic particulate matter mass emissions of organic and elemental carbon are based on the EUCAARI (Kulmala et al., 2009) Pan-
Table 1. Aerosol concentrations (in $\mu \mathrm{g} \mathrm{m}^{-3}$ ) at the boundaries of the domain.

\begin{tabular}{lrrrr}
\hline & \multicolumn{4}{c}{ Boundaries* } \\
\cline { 2 - 5 } Species & North & South & West & East \\
\hline OA & 1 & 0.5 & 0.5 & 1 \\
Sulfate & 1 & 1 & 1 & 1 \\
Ammonium & 0.37 & 0.37 & 0.37 & 0.37 \\
Nitrate & 0.1 & 0.02 & 0.01 & 0.1 \\
Sodium & 0.001 & 0.005 & 0.09 & 0.03 \\
Chloride & 0.002 & 0.01 & 0.1 & 0.05 \\
\hline
\end{tabular}

* "North", "South", "West" and "East" here represent the top, bottom, left and right edge, respectively, of our modeling domain as it is depicted in Fig. 1.

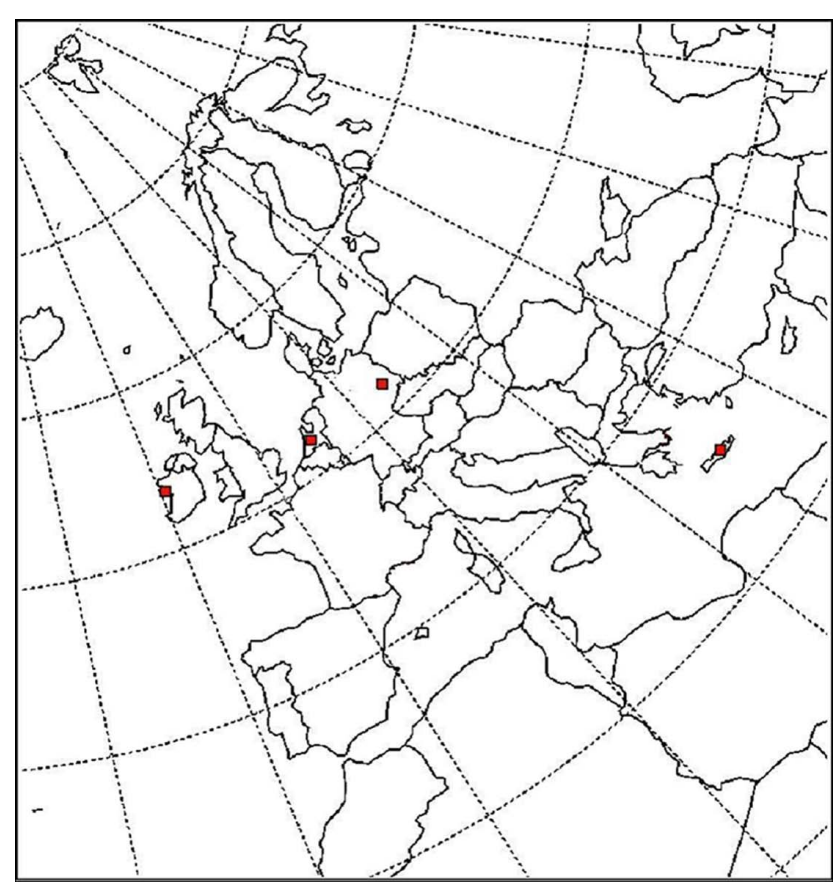

Fig. 1. Modeling domain of PMCAMx-2008 for Europe. Red squares show the measurement stations of Mace Head, Cabauw, Melpitz and Finokalia.

European Carbonaceous Aerosol Inventory. Industrial, domestic, agricultural and traffic emission sources are included in the two inventories. Three different datasets are combined in order to produce the biogenic gridded emissions for the model. Emissions from ecosystems are produced by MEGAN (Model of Emissions of Gases and Aerosols from Nature) (Guenther et al., 2006). MEGAN inputs include the leaf area index, the plant functional type and the emission factors while the weather data needed for MEGAN are provided from the WRF model. The sesquiterpene emissions have been set to $30 \%$ of the monoterpene emissions (Helmig et al., 2006). Since sea surface covers a considerable portion 
Table 2. Emission mass totals (in ktons/month) for the European domain during May 2008.

\begin{tabular}{|c|c|c|c|c|c|c|c|c|c|c|c|c|c|c|}
\hline \multirow[t]{2}{*}{ Species } & \multirow[t]{2}{*}{$\mathrm{CO}$} & \multirow[t]{2}{*}{ NO } & \multirow[t]{2}{*}{$\mathrm{SO}_{2}$} & \multirow{2}{*}{$\mathrm{NH}_{3}$} & \multicolumn{3}{|c|}{ Biogenic VOCs } & \multirow{2}{*}{$\mathrm{NO}_{3}^{-}$} & \multirow[t]{2}{*}{ Sulfate } & \multirow[t]{2}{*}{$\mathrm{NH}_{4}^{+}$} & \multirow[t]{2}{*}{$\mathrm{EC}$} & \multirow[t]{2}{*}{ OC } & \multirow[t]{2}{*}{$\mathrm{Na}^{+}$} & \multirow[t]{2}{*}{$\mathrm{Cl}^{-}$} \\
\hline & & & & & Isop. & $\mathrm{MT}^{1}$ & ovOC $^{2}$ & & & & & & & \\
\hline Anthropogenic & 3682 & 1461 & 1675 & 501 & - & - & 1291 & - & - & - & 59 & 82 & - & - \\
\hline Biogenic (MEGAN) & 439 & 24 & - & - & 892 & 474 & 495 & - & - & - & - & - & - & - \\
\hline Biogenic (Sea salt) & - & - & - & - & - & - & - & - & 1294 & - & - & 43 & 4951 & 8900 \\
\hline Biogenic (Fires) & 768 & 22 & 3 & 11 & - & - & 11 & 7 & 15 & 1 & 16 & 50 & - & - \\
\hline
\end{tabular}

${ }^{1}$ MT: Monoterpene emissions

2 OVOC: Other VOCs excluding methane and methanol

of the domain, the marine aerosol emission model developed by O'Dowd et al. (2008) has been used to estimate mass fluxes for both accumulation and coarse mode including the organic aerosol fraction. Wind speed data from WRF and chlorophyll- $a$ concentrations are the inputs needed for the marine aerosol model. Wildfire emissions from May 2008 were also included (Sofiev et al., 2008a, b). Table 2 shows a summary of the $\mathrm{PM}_{10}$ emission rates from the different sources for the European domain during May 2008. The OA emissions in PMCAMx-2008 were distributed by volatility using the volatility distributions of Tsimpidi et al. (2010).

The model results are compared against hourly mean values from four measurement ground sites in Cabauw (The Netherlands), Finokalia (Greece), Mace Head (Ireland) and Melpitz (Germany). All observation sites are representative of regional atmospheric conditions.

The Cabauw site is located at a rural area in the western part of the Netherlands $\left(51.971^{\circ} \mathrm{N}, 4.927^{\circ} \mathrm{E}\right)$. The nearby region is agricultural while the North Sea is more than $50 \mathrm{~km}$ away to the WNW. During May 2008, aerosol mass spectrometric measurements were performed at the Cabauw station with an Aerodyne High-Resolution Time-of-Flight Aerosol Mass Spectrometer (HR-ToF-AMS) (Morgan et al., 2010a).

The Finokalia sampling station $\left(35.33^{\circ} \mathrm{N}, 25.67^{\circ} \mathrm{E}\right)$ is located at a remote area in the Eastern Mediterranean, in the northern coast of Crete (Greece). The nearest largest urban center (with 150000 inhabitants) is located $70 \mathrm{~km}$ west of Finokalia while no human activities can be found at a distance shorter than $15 \mathrm{~km}$. Located $50 \mathrm{~m}$ from the shore and $230 \mathrm{~m}$ above sea level, the site is a "crossroad" of aged aerosol coming from Europe, the marine boundary layer, the African continent or the biomass burning sources (Mihalopoulos et al., 1997; Koulouri et al., 2008; Bougiatioti et al., 2009). As part of the EUCAARI intensive May 2008 campaign, the Finokalia Aerosol Measurement Experiment 2008 (FAME08) was conducted from 4 May to 8 June 2008 in order to characterize the physical and chemical properties of aged aerosol (Pikridas et al., 2010). A Quadrupole Aerosol Mass Spectrometer (Q-AMS) was employed to measure the sizeresolved chemical composition of non-refractory submicron aerosol $\left(\mathrm{NR}-\mathrm{PM}_{1}\right)$ as well as to estimate the extent of oxida- tion of the organic aerosol (Hildebrandt et al., 2010).

Melpitz is an atmospheric research station in Eastern Germany, $40 \mathrm{~km}$ northeast of Leipzig $\left(12.93^{\circ} \mathrm{E}, 51.54^{\circ} \mathrm{N}\right)$. The station is mainly surrounded by agricultural pastures and forests. Atmospheric aerosol observations at the Melpitz site can be regarded as representative of the regional central European aerosol, confirmed on the basis of a multiple site comparison within the German Ultrafine Aerosol Network (Birmili et al., 2009). A basic overview of the physical and chemical characterization methods can be found in Birmili et al. (2008). The air masses arriving in Melpitz tend to be either Atlantic (westerly) air masses with lower particle mass concentrations or continental (easterly) air masses with higher particle mass concentrations (Engler et al., 2007; Spindler et al., 2010). A HR-ToF-AMS instrument was deployed in this site during May and June 2008 to characterise the size-resolved mass concentrations of the non-refractory sub- $\mu \mathrm{m}$ aerosol.

The Mace Head site $\left(53.32^{\circ} \mathrm{N}, 9.88^{\circ} \mathrm{W}\right)$ is located on the west coast of Ireland on a hilly area (height around $35 \mathrm{~m}$ ) surrounded by a number of small lakes and is exposed to the North Atlantic ocean. It is $88 \mathrm{~km}$ west of Galway (population approximately 60000 ) which is the nearest major city. A HR-ToF-AMS was used to measure mass concentrations of the non-refractory aerosol components from mid-May to mid-June 2008 (Dall'Osto et al., 2010).

As part of the EUCAARI project, the LONG Range EXperiment (LONGREX; http://www.pa.op.dlr.de/aerosol/ eucaari2008/), an aircraft field campaign that took place from 6 to 23 May 2008, aimed at characterizing the distribution of aerosol over Europe via utilisation of airborne in-situ and remote sensing measurements. An Aerodyne Time-of-Flight Aerosol Mass Spectrometer was used to measure the size-resolved chemical composition of nonrefractory particulate matter of widely varying volatility with high time resolution (Morgan et al., 2010a, b). Based at Oberpfaffenhofen (Germany), the aircraft performed flights mainly in West-East and North-South transects across Europe. The LONGREX campaign involved among others an extensively equipped research aircraft, the UK Facility for Airborne Atmospheric Measurements (FAAM) BAe-146 

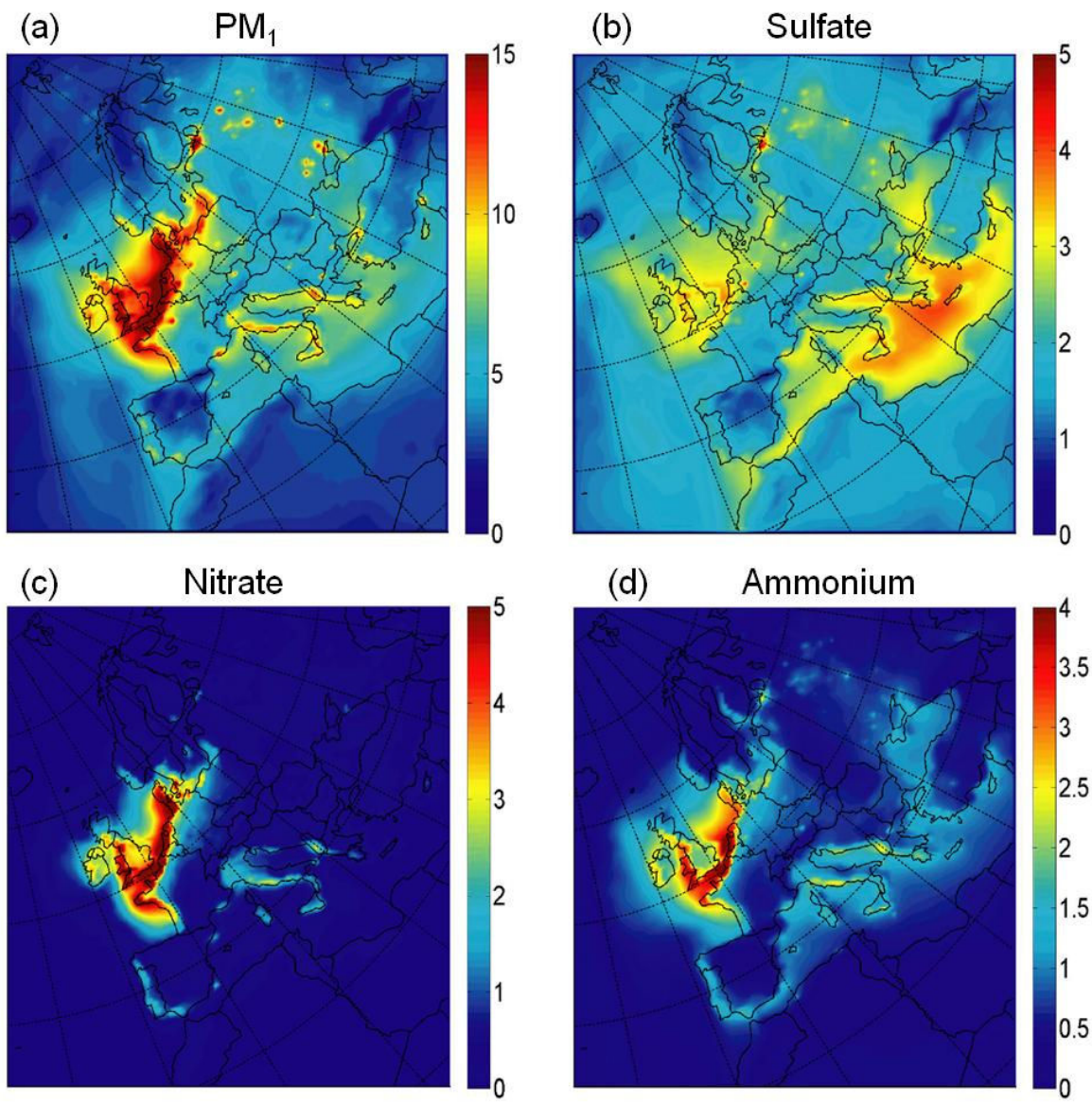

Fig. 2. Ground-level concentration predictions averaged over the entire simulation period (1-29 May 2008) for $\mathrm{PM}_{1}$ (a) total aerosol mass, (b) sulfate, (c) nitrate and (d) ammonium (in $\mu \mathrm{g} \mathrm{m}^{-3}$ ). Different scales are used.

research aircraft, and included a total of 15 flights (approximately 50 flight hours in total).

\subsection{Predicted aerosol concentrations}

Figures 2 and 3 show the PMCAMx-2008 average groundlevel concentrations of $\mathrm{PM}_{1}$ total mass, sulfate, nitrate, ammonium, elemental carbon (EC), OA and its components during the entire period of simulation (1-29 May 2008). Overall, OA is predicted to account for $32 \%$ of total $\mathrm{PM}_{1}$ at ground level averaged over the entire domain, followed by sulfate $(30 \%)$, ammonium (13\%), nitrate $(7 \%)$, and finally EC $(4 \%)$. The remaining $14 \%$ is crustal material, sea-salt and metal oxides. The highest predicted concentrations for fine sulfate are over the Eastern Mediterranean region while nitrate concentrations are the highest over a wide area from west of England to Denmark with a predicted maximum of $6.5 \mu \mathrm{g} \mathrm{m}^{-3}$ at the north coast of France. $\mathrm{PM}_{1}$ nitrate concentrations in the rest of the domain are generally low, less than $1 \mu \mathrm{g} \mathrm{m}^{-3}$ in most areas. Ammonium concentrations show a similar pattern with nitrate in the domain. Elevated ammo- nium concentrations show strong association with nitrate, evidence of $\mathrm{NH}_{4} \mathrm{NO}_{3}$ formation in the specific area.

The average ground concentrations of "fresh" POA, oxidized POA, anthropogenic SOA, biogenic SOA, EC and total OA predicted by PMCAMx-2008 are shown in Fig. 3. Fresh POA concentrations are relatively high (up to $7 \mu \mathrm{g} \mathrm{m}^{-3}$ ) in various urban and suburban areas mainly in central and Northern Europe and drop dramatically (less than $0.5 \mu \mathrm{g} \mathrm{m}^{-3}$ ) in the rest of the domain (Fig. 3a). Less than $7 \%$ of total $\mathrm{PM}_{1} \mathrm{OA}$ is predicted to consist of fresh POA on average over the entire domain with a maximum of $70 \%$ in the area of St. Petersburg, northwest of Russia. OPOA concentrations are predicted to be higher than the fresh POA in the modeling domain with an average of $52 \%$ contribution to total OA. The model indicates that much of the traditionally thought as particulate primary OA emissions are actually evaporating to produce low-volatility organic vapors which are the source (through photochemical aging) of a substantial amount of oxygenated OA that is distributed not only in urban and suburban areas but rural regions as well. Oxidized POA is predicted to be the dominant OA component 


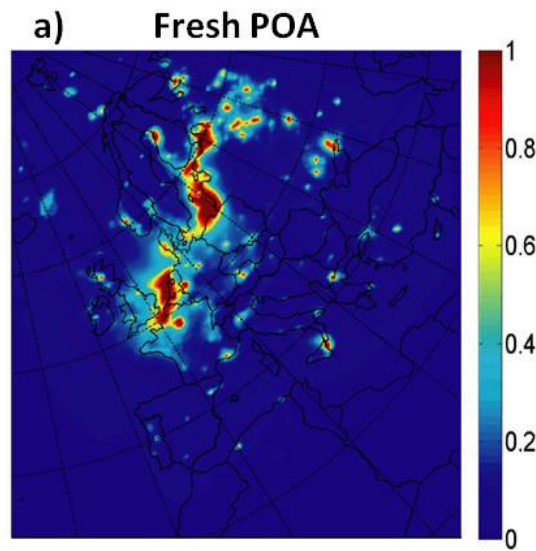

c) Anthropogenic SOA

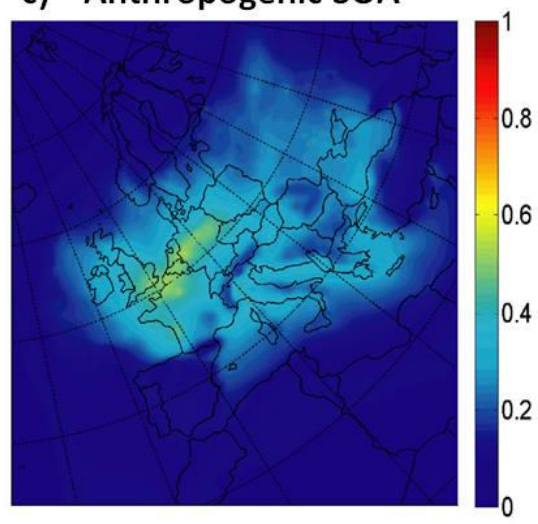

e)

EC

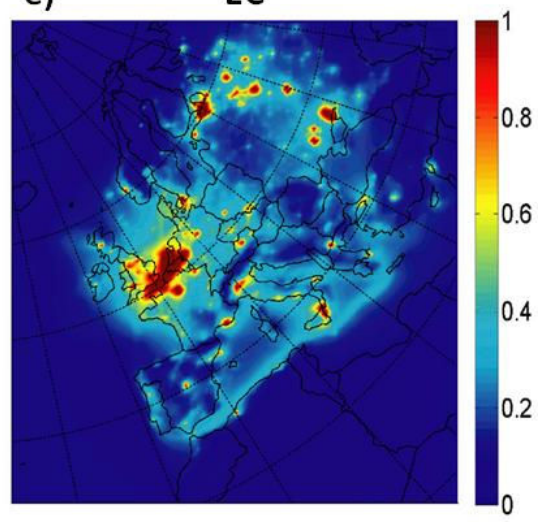

b) Oxidized POA

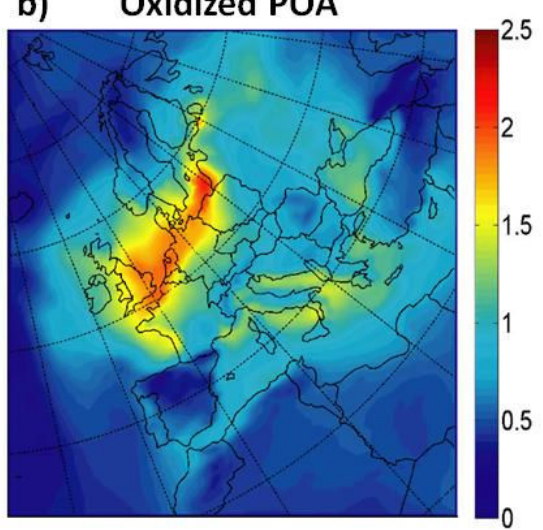

d) Biogenic SOA

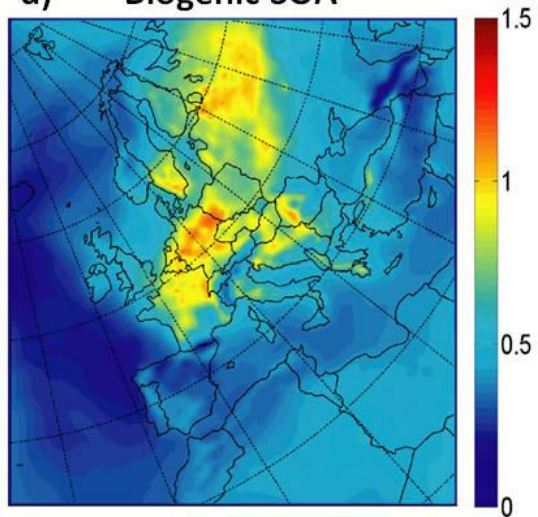

f)

OA

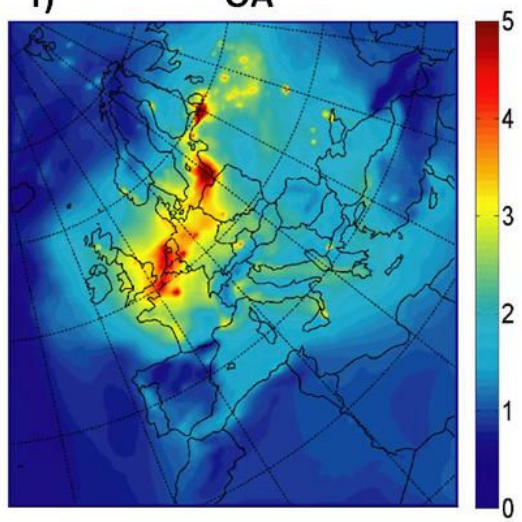

Fig. 3. Ground-level concentration predictions averaged over the entire simulation period (1-29 May 2008) for $\mathrm{PM}_{1}$ (a) "fresh" $\mathrm{POA}$, (b) oxidized POA, (c) anthropogenic SOA, (d) biogenic SOA, (e) elemental carbon and (f) total organic aerosol (in $\mu \mathrm{g} \mathrm{m}^{-3}$ ). Different scales are used.

during this period contributing $56 \%$ to the total oxygenated OA (sum of OPOA, SOA and BC-OA) in the modeling domain. Biogenic SOA comprises on average almost one third of the total predicted OA over the domain while almost $35 \%$ of the total oxygenated OA consists of bSOA. The highest absolute concentrations are predicted over Germany with a peak value of $1.2 \mu \mathrm{g} \mathrm{m}^{-3}$. However, biogenic SOA is the dominant OA component over a large area covering NE of
Serbia, Romania and West of Ukraine where the contribution of bSOA to total OA ranges from 40 to $50 \%$. Anthropogenic SOA concentrations are predicted to be generally low in the modeling domain (less than $0.5 \mu \mathrm{g} \mathrm{m}^{-3}$ in most areas). Elevated aSOA concentrations are predicted in the area covering England, North of France, Belgium, the Netherlands and west of Germany. The model predicts an almost uniform distribution of aged organic aerosol transported into the 
domain from the boundaries $\left(\sim 0.5 \mu \mathrm{g} \mathrm{m}^{-3}\right)$. An average of $0.2 \mu \mathrm{g} \mathrm{m}^{-3}$ is predicted for $\mathrm{PM}_{1} \mathrm{EC}$ concentrations in the domain, although much higher values are predicted locally (up to $4 \mu \mathrm{g} \mathrm{m}^{-3}$ ) in urban areas.

Organic matter is predicted to be the dominant $\mathrm{PM}_{1}$ component in central and northern Europe with a peak value of approximately $10 \mu \mathrm{g} \mathrm{m}^{-3}$ (in northwestern Russia). The average monthly contribution of $\mathrm{OA}$ to total $\mathrm{PM}_{1}$ mass ranges from 35 to $50 \%$ in central and northern Europe and drops to $15-30 \%$ at the rest of the domain (Fig. 4a). The eastern Mediterranean region is the only area in Europe where sulfate concentrations are predicted to be much higher than the OA values among the $\mathrm{PM}_{1}$ species (Fig. 4b). Unlike the rest of Europe, sulfate levels over the Mediterranean are almost 2 times larger than the OA levels. In central and northern Europe, PMCAMx-2008 predicts the opposite with an average OA to sulfate mass ratio of 2.5. These higher sulfate levels over the Mediterranean are due to the transport of sulfur dioxide and the resulting sulfates originating from the Balkans and the industrial areas of eastern Europe (Sciare et al., 2003; Lelieveld et al., 2002; Ganor et al., 2000; Mihalopoulos et al., 1997) plus additional contributions of sulfur dioxide from shipping and DMS from phytoplankton. The intense sunlight and photochemistry in this area convert rapidly the transported sulfur dioxide from less photochemically active areas to sulfate.

\section{Model evaluation}

The prediction skill of PMCAMx-2008 is quantified in terms of the normalized mean bias (NMB), the normalized mean error (NME), the mean bias (MB), the mean absolute gross error (MAGE), the fractional bias (FBIAS), and the fractional error (FERROR),

$\mathrm{NMB}=\sum_{i=1}^{n}\left(P_{i}-O_{i}\right) / \sum_{i=1}^{n} O_{i}$

$\mathrm{NME}=\sum_{i=1}^{n}\left|P_{i}-O_{i}\right| / \sum_{i=1}^{n} O_{i}$

$\mathrm{MB}=1 / n \sum_{i=1}^{n}\left(P_{i}-O_{i}\right) \quad \mathrm{MAGE}=1 / n \sum_{i=1}^{n}\left|P_{i}-O_{i}\right|$

FBIAS $=2 / n \sum_{i=1}^{n}\left(P_{i}-O_{i}\right) /\left(P_{i}+O_{i}\right)$

FERROR $=2 / n \sum_{i=1}^{n}\left|P_{i}-O_{i}\right| /\left(P_{i}+O_{i}\right)$

where $P_{i}$ represents the model predicted value for data point $i, O_{i}$ is the corresponding observed value and $n$ is the total number of data points. The prediction skill metrics of PMCAMx-2008 against AMS hourly ground measurements from 4 stations are summarized in Table 3.

PMCAMx-2008 predictions agree reasonably well with the AMS measurements at Cabauw for all species. The measured monthly average concentrations for OA, nitrate, sulfate
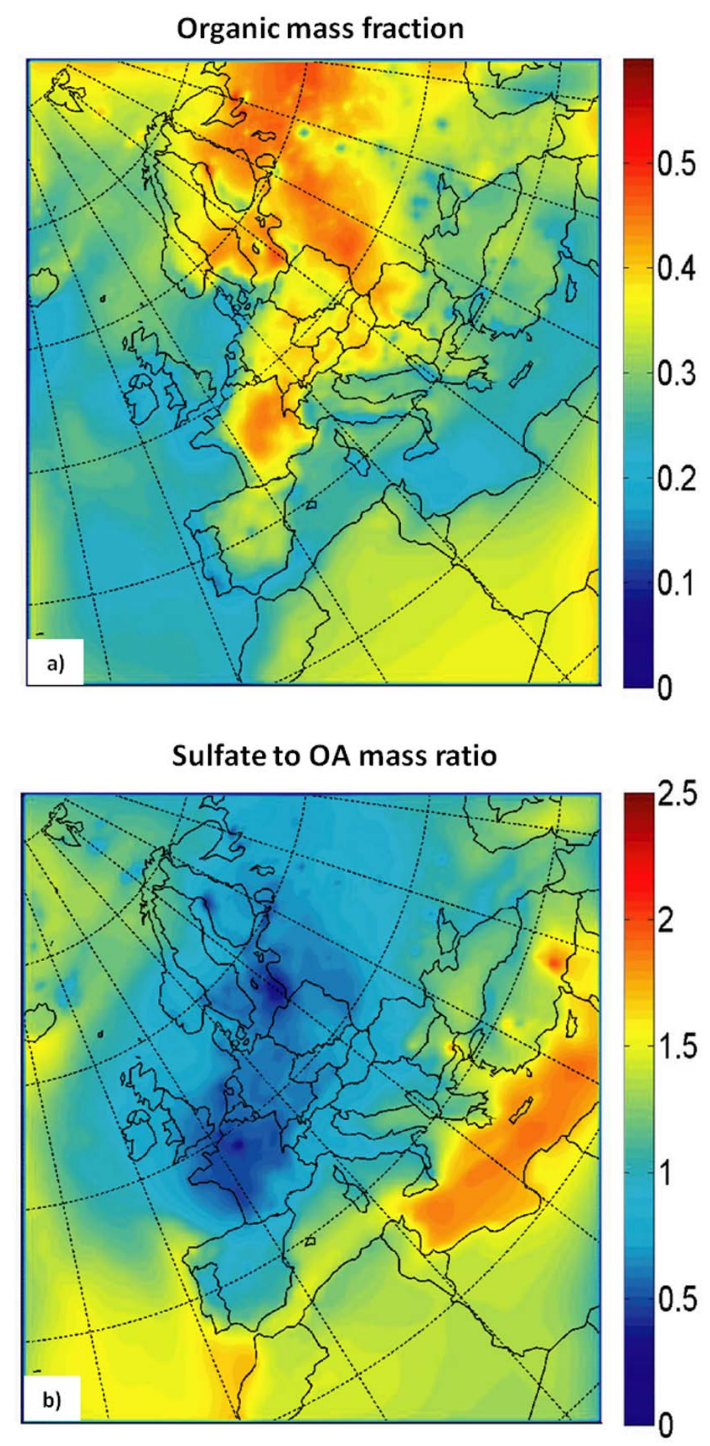

Fig. 4. Contribution of (a) organic aerosol to total $\mathrm{PM}_{1}$ mass and, (b) $\mathrm{PM}_{1}$ sulfate to OA mass ratio averaged over the entire simulation period (1-29 May 2008).

and ammonium were $4.1,2.5,1.5$ and $1.7 \mu \mathrm{g} \mathrm{m}^{-3}$ respectively compared to the predicted average of 4.0, 3.2, 2.2 and $1.9 \mathrm{\mu g} \mathrm{m}^{-3}$. The model reproduces more than $89 \%$ of the hourly $\mathrm{PM}_{1} \mathrm{OA}$ data within a factor of 2 . In agreement with the AMS measurements, the model predicts that OA makes up the largest portion of the $\mathrm{PM}_{1}$ total mass in Cabauw, followed by nitrate, sulfate and ammonium. OA is predicted to be mostly dominated by oxygenated OA components ( $77 \%$ contribution) characteristic of rural areas in the northern Hemisphere (Zhang et al., 2007). Oxidized POA makes up most $(60 \%)$ of the oxygenated OA aerosol in Cabauw with a monthly average predicted value of $1.8 \mu \mathrm{g} \mathrm{m}^{-3}$.

Figure 5 shows the predicted and measured timeseries of $\mathrm{PM}_{1} \mathrm{OA}$, sulfate, and ammonium concentrations at Finokalia 
Table 3. Prediction skill metrics of PMCAMx-2008 against AMS hourly ground measurements from 4 stations (Cabauw, Finokalia, Mace Head, Melpitz) during the EUCAARI campaign in May 2008*.

\begin{tabular}{|c|c|c|c|c|c|c|c|c|c|}
\hline $\mathrm{PM}_{1}$ & $\begin{array}{r}\text { Mean } \\
\text { Observed } \\
\left(\mu \mathrm{g} \mathrm{m}^{-3}\right)\end{array}$ & $\begin{array}{r}\text { Mean } \\
\text { Predicted } \\
\left(\mu \mathrm{g} \mathrm{m}^{-3}\right)\end{array}$ & $\begin{array}{r}\mathrm{MB} \\
\left(\mu \mathrm{g} \mathrm{m}^{-3}\right)\end{array}$ & $\begin{array}{r}\text { MAGE } \\
\left(\mu \mathrm{g} \mathrm{m}^{-3}\right)\end{array}$ & $\begin{array}{r}\text { NMB } \\
(\%)\end{array}$ & $\begin{array}{r}\text { NME } \\
(\%)\end{array}$ & FBIAS & FERROR & $\begin{array}{r}\text { Percent } \\
\text { within a } \\
\text { factor of } 2\end{array}$ \\
\hline \multicolumn{10}{|c|}{ Cabauw } \\
\hline OA & 4.1 & 4.0 & -0.1 & 1.1 & -3 & 27 & 0.005 & 0.3 & 89 \\
\hline Sulfate & 1.5 & 2.2 & 0.7 & 1.1 & 49 & 72 & 0.3 & 0.5 & 60 \\
\hline Nitrate & 2.5 & 3.2 & 0.8 & 1.7 & 33 & 71 & 0.3 & 0.7 & 53 \\
\hline Ammonium & 1.7 & 1.9 & 0.2 & 0.7 & 15 & 42 & 0.1 & 0.4 & 76 \\
\hline \multicolumn{10}{|c|}{ Finokalia } \\
\hline OA & 2.5 & 2.1 & -0.4 & 0.7 & -16 & 30 & -0.1 & 0.3 & 92 \\
\hline Sulfate & 5.2 & 4.7 & -0.5 & 2.0 & -9 & 38 & -0.005 & 0.4 & 83 \\
\hline Nitrate & 0.08 & 0.09 & 0.02 & 0.1 & - & - & - & - & - \\
\hline Ammonium & 1.5 & 1.3 & -0.2 & 0.5 & -16 & 38 & -0.1 & 0.4 & 83 \\
\hline \multicolumn{10}{|c|}{ Mace Head } \\
\hline OA & 2.3 & 2.0 & -0.4 & 0.8 & -18 & 35 & -0.2 & 0.4 & 79 \\
\hline Sulfate & 1.8 & 1.7 & -0.1 & 0.7 & -7 & 40 & -0.1 & 0.4 & 74 \\
\hline Nitrate & 0.8 & 3.2 & 2.4 & 2.6 & 298 & 320 & 1.1 & 1.2 & 16 \\
\hline Ammonium & 1.0 & 2.5 & 1.5 & 1.6 & 158 & 165 & 0.8 & 0.9 & 23 \\
\hline \multicolumn{10}{|c|}{ Melpitz } \\
\hline OA & 5.1 & 3.7 & -1.4 & 1.6 & -29 & 32 & -0.3 & 0.3 & 81 \\
\hline Sulfate & 2.3 & 2.1 & -0.2 & 1.1 & -10 & 49 & -0.1 & 0.4 & 65 \\
\hline Nitrate & 0.7 & 0.5 & -0.1 & 0.4 & -25 & 58 & -0.6 & 0.8 & 43 \\
\hline Ammonium & 1.0 & 0.9 & -0.01 & 0.4 & -1 & 47 & -0.02 & 0.4 & 70 \\
\hline \multicolumn{10}{|c|}{ Overall } \\
\hline OA & 3.3 & 3.0 & -0.4 & 1.0 & -11 & 30 & -0.1 & 0.3 & 87 \\
\hline Sulfate & 2.8 & 2.9 & 0.1 & 1.3 & 3 & 47 & 0.1 & 0.4 & 70 \\
\hline Nitrate & 1.7 & 2.8 & 1.1 & 1.8 & 67 & 105 & 0.4 & 0.8 & 41 \\
\hline Ammonium & 1.5 & 1.7 & 0.3 & 0.8 & 23 & 58 & 0.2 & 0.5 & 67 \\
\hline
\end{tabular}

* Number of datapoints; Cabauw: 640, Finokalia: 490, Mace Head: 330, Melpitz: 160.

during the EUCAARI May 2008 campaign. The average predicted concentration is $2.1 \mu \mathrm{g} \mathrm{m}^{-3}$ for total OA, $4.7 \mu \mathrm{g} \mathrm{m}^{-3}$ for sulfate, $1.3 \mu \mathrm{g} \mathrm{m}^{-3}$ for ammonium and $0.09 \mu \mathrm{g} \mathrm{m}^{-3}$ for nitrate compared to the AMS measurements of $2.5 \mu \mathrm{g} \mathrm{m}^{-3}$, $5.2 \mu \mathrm{g} \mathrm{m}^{-3}, 1.5 \mu \mathrm{g} \mathrm{m}^{-3}$ and $0.08 \mu \mathrm{g} \mathrm{m}^{-3}$ respectively. Filter measurements indicated somewhat lower average values for OA $\left(2.3 \mu \mathrm{g} \mathrm{m}^{-3}\right)$, sulfate $\left(4.7 \mu \mathrm{g} \mathrm{m}^{-3}\right)$ and ammonium $\left(1.3 \mu \mathrm{g} \mathrm{m}^{-3}\right)$ compared to the AMS (Pikridas et al., 2010). In agreement with observations, $\mathrm{PM}_{1}$ nitrate (not shown) is predicted to be low (less than $0.1 \mu \mathrm{g} \mathrm{m}^{-3}$ ) throughout the month. Due to very low concentrations of nitrate in Finokalia, the NMB, NME, FBIAS, FERROR and the "percent within a factor of 2" are not included in Table 3. Contrary to the Cabauw site, the dominant $\mathrm{PM}_{1}$ species at the Finokalia station is sulfate as shown both from the AMS and filter measurements and the model predictions. The model predicts oxidized POA (including IVOC oxidation) to be the dominant species among OOA components with $60 \%$ contribution, followed by bSOA (23\%) and aSOA (17\%). Compared to a positive matrix factorization analysis of the organic aerosol AMS data at Finokalia (Hildebrandt et al., 2010), PMCAMx2008 correctly predicts negligible HOA concentrations at Finokalia $\left(\sim 0.02 \mu \mathrm{g} \mathrm{m}^{-3}\right)$ a result of no strong local sources and rapid conversion of POA to OPOA. On average, both AMS and PMCAMx-2008 give high (more than $98 \%$ of total OA) oxygenated organic aerosol concentrations. A more detailed analysis of the comparison between model predicted concentrations of OA components and the PMF analysis of AMS data from various European sites will be presented in a forthcoming paper.

At Mace Head, the model predicts reasonably well both $\mathrm{PM}_{1} \mathrm{OA}$ and sulfate, reproducing $79 \%$ and $74 \%$ of the hourly data within a factor of 2 . However, much larger errors are seen for $\mathrm{PM}_{1}$ nitrate and ammonium. This is because of 

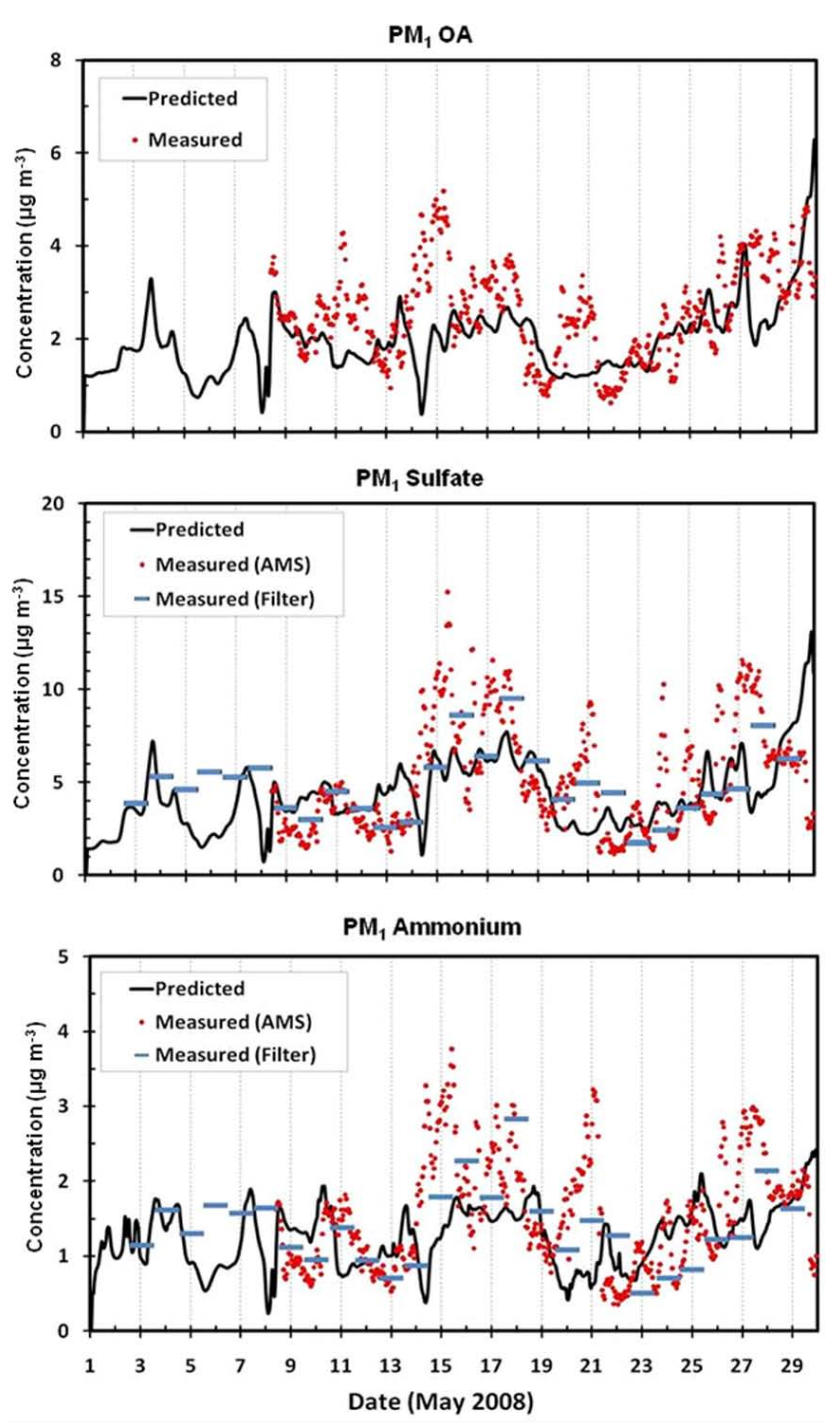

Fig. 5. Comparison of model predictions with measurements of $\mathrm{PM}_{1} \mathrm{OA}$, sulfate, and ammonium (in $\mu \mathrm{g} \mathrm{m}^{-3}$ ) taken at Finokalia during the EUCAARI May 2008 campaign.

the bulk equilibrium assumption and the fact that a significant amount of nitrate in Mace Head is associated with seasalt which shifts nitrate and ammonium to the coarse mode (Dall'Osto et al., 2010). This was also seen in the highdust concentration area of Mexico City (Karydis et al., 2010) where the bulk equilibrium approach of PMCAMx-2008 was unable to capture this effect, thus significantly underpredicting concentrations of nitrate and ammonium in the coarse mode and overpredicting in the fine mode.

Encouraging agreement with the AMS data is also seen in Melpitz although measurements from only the last week of May were available. Among the 4 stations, the OA concentrations in Melpitz are the highest as shown both from measurements and model predictions. The model reproduces more than $81 \%$ of the hourly $\mathrm{PM}_{1}$ OA data within a factor of 2 .
The diurnal profiles of $\mathrm{OA}$ and sulfate concentrations from 2 major cities and 2 rural areas are shown in Fig. 6. The model predicts relatively flat average diurnal profiles in both the rural and urban cites. At the two rural areas, the predicted diurnal profile of both sulfate and total OA do not vary significantly, in agreement with the observations. At Cabauw, the highest average value for $\mathrm{PM}_{1} \mathrm{OA}$ was observed and predicted to be 4.7 and $4.3 \mu \mathrm{g} \mathrm{m}^{-3}$ respectively, both at the same time (07:00 a.m. UTC). At Finokalia, the model underpredicts the observed OA by roughly $20 \%$ while it succeeds in reproducing the high degree of oxidation in the eastern Mediterranean. It captures the small increase of the observed OA concentrations in the afternoon. The relatively flat diurnal profiles that the model tends to predict in many areas, are rather surprising considering the expected diurnal variations due to emissions, photochemical activity and temperature changes. Previous modeling efforts suggested strong diurnal OA variation that is in most cases inconsistent with observations (Pun et al., 2003).

Overall, the model agreement with the AMS ground measurements is encouraging. A scatter plot of the comparison for $\mathrm{PM}_{1}$ sulfate and OA is shown in Fig. 7. More than $87 \%$ of the (hourly) data points for $\mathrm{PM}_{1} \mathrm{OA}$ and $70 \%$ for sulfate lay within the 1:2 and 2:1 error lines. Model predictions for sulfate were subject to significant scatter $(\mathrm{NME}=47 \%$, mean error $=1.3 \mu \mathrm{g} \mathrm{m}^{-3}$, FERROR $\left.=0.4\right)$. The normalized mean bias for the OA was only $11 \%$ (small underprediction) and the corresponding mean bias $-0.4 \mu \mathrm{g} \mathrm{m}^{-3}$. Larger errors are seen for aerosol nitrate and ammonium which could be partly attributed to the use of the bulk equilibrium approach for the simulation of the inorganic aerosol growth. The model significantly overpredicts both nitrate and ammonium in Mace Head but does a reasonable job elsewhere. If the data points from Mace Head are excluded from the statistical analysis, the NMB is reduced from 67 to $29 \%$ for $\mathrm{PM}_{1}$ nitrate and from 24 to $2 \%$ for $\mathrm{PM}_{1}$ ammonium while significantly reducing the mean bias to 0.4 and $0.03 \mu \mathrm{g} \mathrm{m}^{-3}$, respectively. Compared to the daily averaged measurement values, the model performs well reproducing more than $94 \%$ and $82 \%$ of the hourly data within a factor of 2 for OA and sulfate, respectively.

The capability of the model to reproduce the vertical distribution of sub-micron aerosol chemical composition is evaluated by comparing its predictions with the airborne AMS data. Figure 8 shows predicted and observed vertical concentration profiles of the aerosol chemical species calculated for $500 \mathrm{~m}$ altitude bins averaged over the entire EUCAARILONGREX campaign. The overall agreement of PMCAMx2008 predictions with the LONGREX airborne data is encouraging. Contrary to previous studies (Heald et al., 2005) that found high concentrations of SOA in the free troposphere over the NW Pacific during the ACE-Asia campaign, both PMCAMx-2008 and the observations reveal low OA concentrations in the $2-6 \mathrm{~km}$ altitude range over Europe during May 2008. Table 4 shows statistical metrics of the 

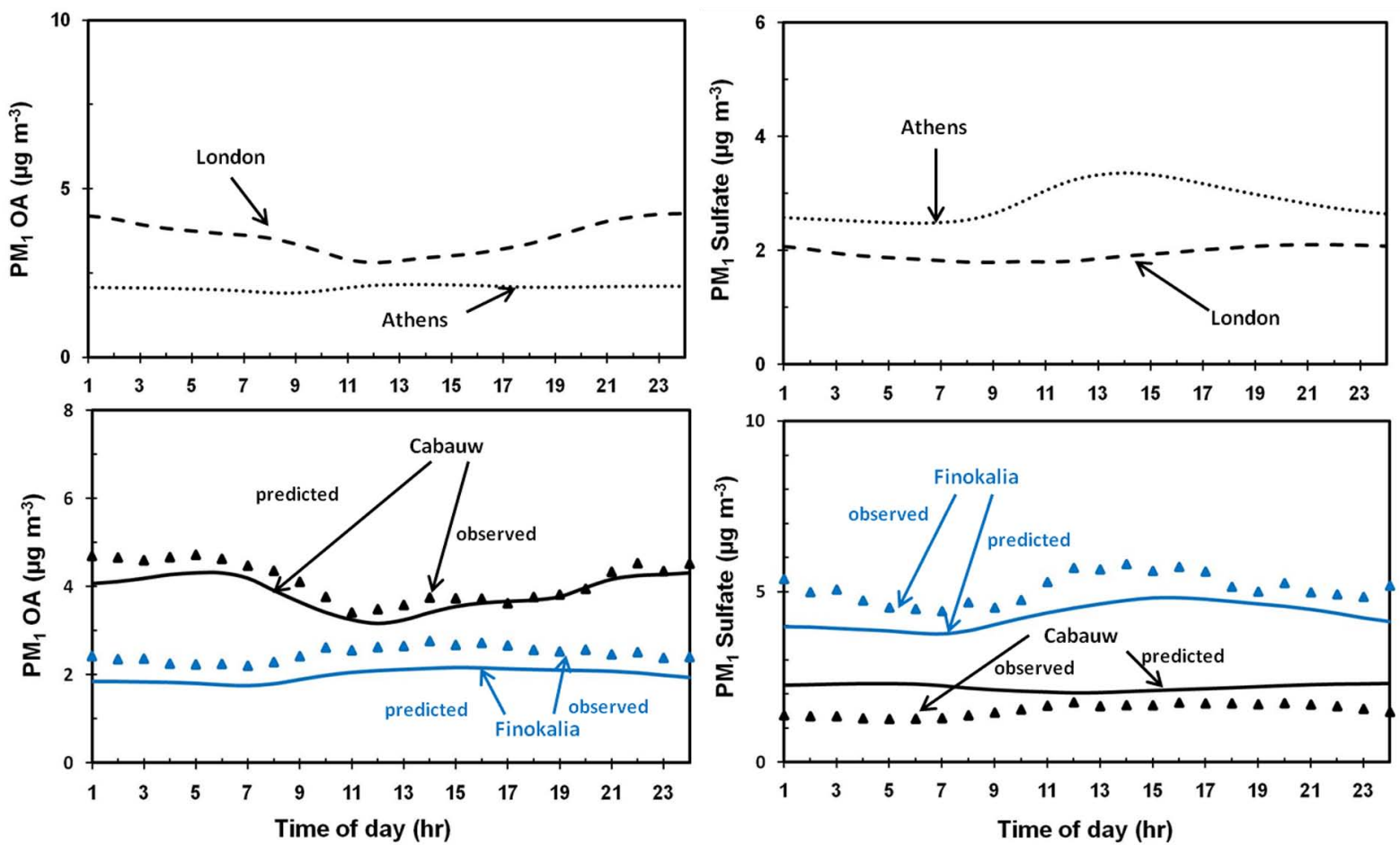

Fig. 6. Average diurnal profiles of $\mathrm{PM}_{1} \mathrm{OA}$ and sulfate at 2 urban and 2 rural sites during the EUCAARI May 2008 campaign. Profiles for London and Athens represent predicted values.

Table 4. Prediction skill metrics of PMCAMx-2008 against AMS airborne measurements during the EUCAARI-LONGREX campaign in May 2008*.

\begin{tabular}{|c|c|c|c|c|c|c|c|c|c|}
\hline $\mathrm{PM}_{1}$ & $\begin{array}{r}\text { Mean } \\
\text { Observed } \\
\left(\mu \mathrm{g} \mathrm{m}^{-3}\right)\end{array}$ & $\begin{array}{r}\text { Mean } \\
\text { Predicted } \\
\left(\mu \mathrm{g} \mathrm{m}^{-3}\right)\end{array}$ & $\begin{array}{r}\text { MB } \\
\left(\mu \mathrm{g} \mathrm{m}^{-3}\right)\end{array}$ & $\begin{array}{r}\text { MAGE } \\
\left(\mu \mathrm{g} \mathrm{m}^{-3}\right)\end{array}$ & $\begin{array}{r}\text { NMB } \\
(\%)\end{array}$ & $\begin{array}{r}\text { NME } \\
(\%)\end{array}$ & FBIAS & FERROR & $\begin{array}{r}\text { Percent } \\
\text { within a } \\
\text { factor of } 2\end{array}$ \\
\hline $\mathrm{OA}$ & 2.6 & 2.2 & -0.4 & 1.1 & -15 & 42 & -0.2 & 0.6 & 66 \\
\hline Sulfate & 1.6 & 1.6 & -0.1 & 0.8 & -3 & 51 & 0.2 & 0.6 & 62 \\
\hline Nitrate & 1.6 & 1.4 & -0.2 & 1.1 & -14 & 69 & -0.3 & 1.0 & 38 \\
\hline Ammonium & 1.2 & 1.3 & 0.01 & 0.7 & 1 & 57 & -0.08 & 0.7 & 53 \\
\hline
\end{tabular}

* 7010 data points.

comparison between the airborne AMS data and PMCAMx2008 predictions. Compared to the ground measurements, the scatter in this comparison is larger yet expected since the model predicted values are compared against each one of the AMS measurements (total of $~ 7000$ points) instead of comparing hourly averages. The model can correctly predict both the $\mathrm{OA}$ and sulfate concentrations to within a factor of 2 of the observations for the majority of the data points $(>66 \%$ and $>62 \%$ respectively). When the observed concentrations for OA and sulfate are higher than $1.0 \mathrm{\mu g} \mathrm{m}^{-3}$ the model reproduces more than $75 \%$ and $77 \%$ of the data within a factor of 2 for both species respectively. The ability of the model to reproduce the high time resolution airborne measurements at multiple altitudes and locations is quite similar to its ability to capture the ground level (hourly) observations.

\section{Sensitivity tests}

There are several possible sources of bias in the model predictions including the volatility distribution of the primary organic aerosol emissions, the simple parameterization of the chemical aging of the OA, emission errors in either the anthropogenic or biogenic emissions or errors in the meteorological input, etc. These uncertainties have been discussed in previous studies (Lane et al., 2008a, b; Murphy et al., 2009, 2011; Tsimpidi et al., 2010, 2011). We explore here the role of the assumed aging in biogenic SOA and the enthalpies of vaporization $\left(\Delta H_{\mathrm{vap}}\right)$ for $\mathrm{SOA}$.

Assuming that biogenic SOA age with the same aging rate constant as the anthropogenic SOA, results in a significant increase of OA concentrations predicted by the model in all 

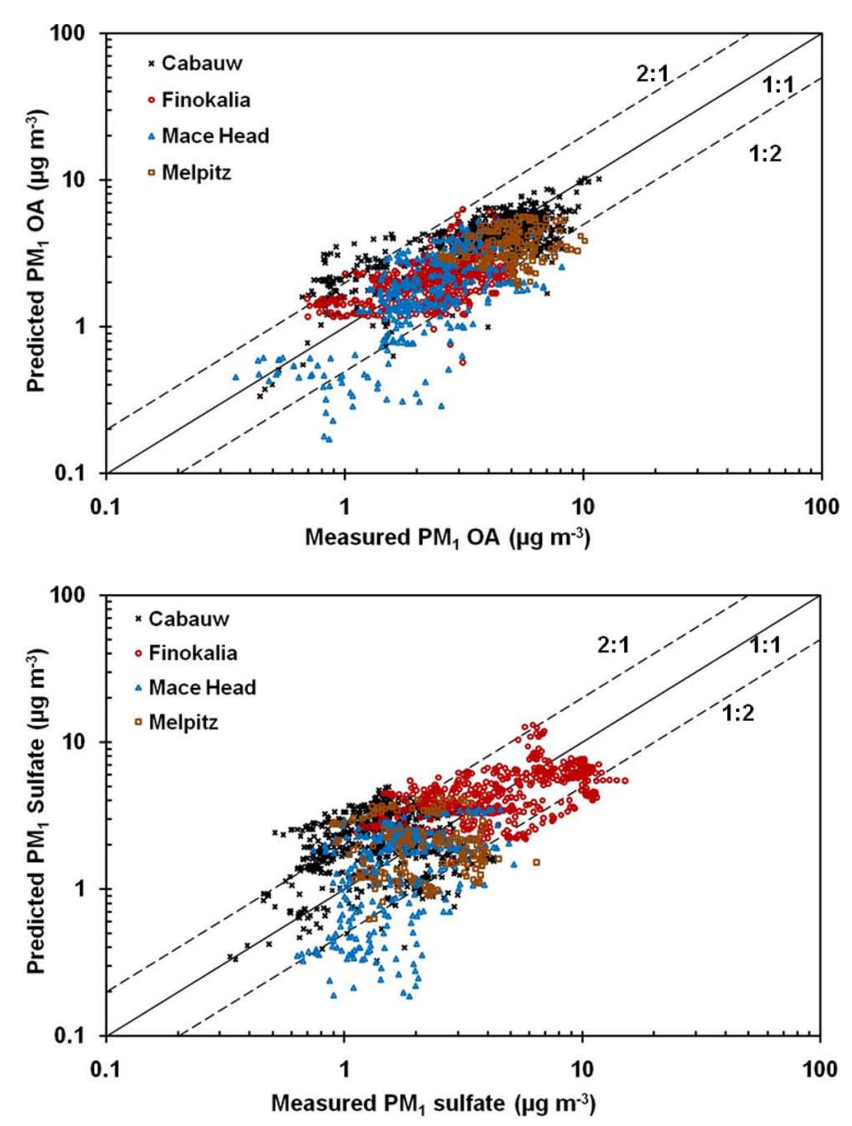

Fig. 7. Comparison of predicted vs. observed $\mathrm{PM}_{1}$ organic matter and sulfate concentrations $\left(\mu \mathrm{g} \mathrm{m}^{-3}\right)$ from 4 measurement stations during the EUCAARI May 2008 campaign. Each point corresponds to a 1-h average value. Also shown the 1:1,2:1 and 1:2 lines. Observed data represent AMS measurements. The slope of the line for OA is $0.814(R=0.65)$ and for sulfate $0.811(R=0.38)$.

4 stations. At Cabauw the model predicts a monthly average concentration of $5.7 \mu \mathrm{g} \mathrm{m}^{-3}$ for total $\mathrm{PM}_{1} \mathrm{OA}$, resulting in an overprediction of the measured OA by more than $40 \%$. In Finokalia, including biogenic SOA aging increases the predicted OA by almost $90 \%$ compared to the basecase simulation, a result of strong photochemical activity in this area during the period of simulation. This results in a strong overprediction of the OA in Finokalia. In Mace Head the resulting increase in the predicted $\mathrm{PM}_{1} \mathrm{OA}$ is more than $60 \%$ compared to the basecase while in Melpitz this sensitivity run increased the predicted OA by $85 \%$. The above results indicate that including a significant increase of the biogenic SOA levels due to chemical aging leads to a significant overprediction of the OA levels in all stations.

Temperature sensitivity is an important issue in simulating OA formation, especially when looking at the performance of the model against the airborne data. For this test, we only vary the $\Delta H_{\text {vap }}$ of aSOA and bSOA, as the POA and OPOA species have vaporization enthalpies that vary with volatility consistent with Murphy and Pandis (2009). Fol- lowing the work of Murphy et al. (2011), two values for the enthalpy of vaporization (50 and $75 \mathrm{~kJ} \mathrm{~mol}^{-1}$ ) are chosen to represent both the aSOA and bSOA species, independent of their volatility, while the basecase run uses $\Delta H_{\mathrm{vap}}=$ $30 \mathrm{~kJ} \mathrm{~mol}^{-1}$. As the enthalpy of vaporization is increased, the predicted OA mass tends to increase. For the first sensitivity test $\left(\Delta H_{\mathrm{vap}}=50 \mathrm{~kJ} \mathrm{~mol}^{-1}\right)$ the model predicted OA mass slightly increases (by less than $4 \%$ ) both at the ground and also aloft. Increasing $\Delta H_{\text {vap }}$ to $75 \mathrm{~kJ} \mathrm{~mol}^{-1}$, results in an increase of OA mass by approximately $7 \%$ in the first km altitude while the OA concentration increase ranges from 9 to $12 \%$ for higher altitudes. This is consistent with Murphy et al. (2011) who showed that for the eastern US, surface OA concentration predictions by PMCAMx-2008 are not very sensitive to the choice of SOA vaporization enthalpy.

\section{Conclusions}

A detailed three dimensional CTM, PMCAMx-2008, was applied to the European domain for the first time, in order to simulate the chemical composition and mass of the major $\mathrm{PM}_{1}$ components during the month of May 2008 during which an intensive campaign of measurements was performed in Europe as part of the EUCAARI project. PMCAMx-2008 assumes that both primary and secondary organic aerosol are semivolatile and photochemically reactive. On a domain-average basis, the model predicts organics to account for $32 \%$ of total $\mathrm{PM}_{1}$ at ground level during May 2008 , followed by sulfate $(30 \%)$, ammonium $(13 \%)$, nitrate (7\%), and finally elemental carbon $(4 \%)$. The model performance is evaluated against ground measurements taken at 4 European measurement stations as well as airborne measurements from an aircraft field campaign over Europe. The comparison of the model predictions with hourly average Aerosol Mass Spectrometry (AMS) ground measurements is encouraging. The model reproduces more than $87 \%$ of the hourly data and more than $94 \%$ of the daily averaged data within a factor of 2 , for $\mathrm{PM}_{1} \mathrm{OA}$. The model performs well in reproducing the high degree of oxidation as well as the average diurnal profile of the organic concentrations observed in the Eastern Mediterranean region. The capability of the model to reproduce the vertical distribution of sub-micron aerosol chemical composition was evaluated by comparing its predictions with the airborne AMS data from 15 flights. The model performance against the high time resolution airborne measurements of OA and sulfate at multiple altitudes and locations is quite similar to its performance against the ground level hourly measurements.

The model predicts that the Mediterranean region is the only area in Europe where $\mathrm{PM}_{1}$ sulfate concentrations are much higher than the $\mathrm{PM}_{1} \mathrm{OA}$ during late spring, while organic matter is predicted to be the dominant $\mathrm{PM}_{1}$ species over a large part of continental Europe. The model predicts low levels of fresh POA and a ubiquity of oxygenated species 

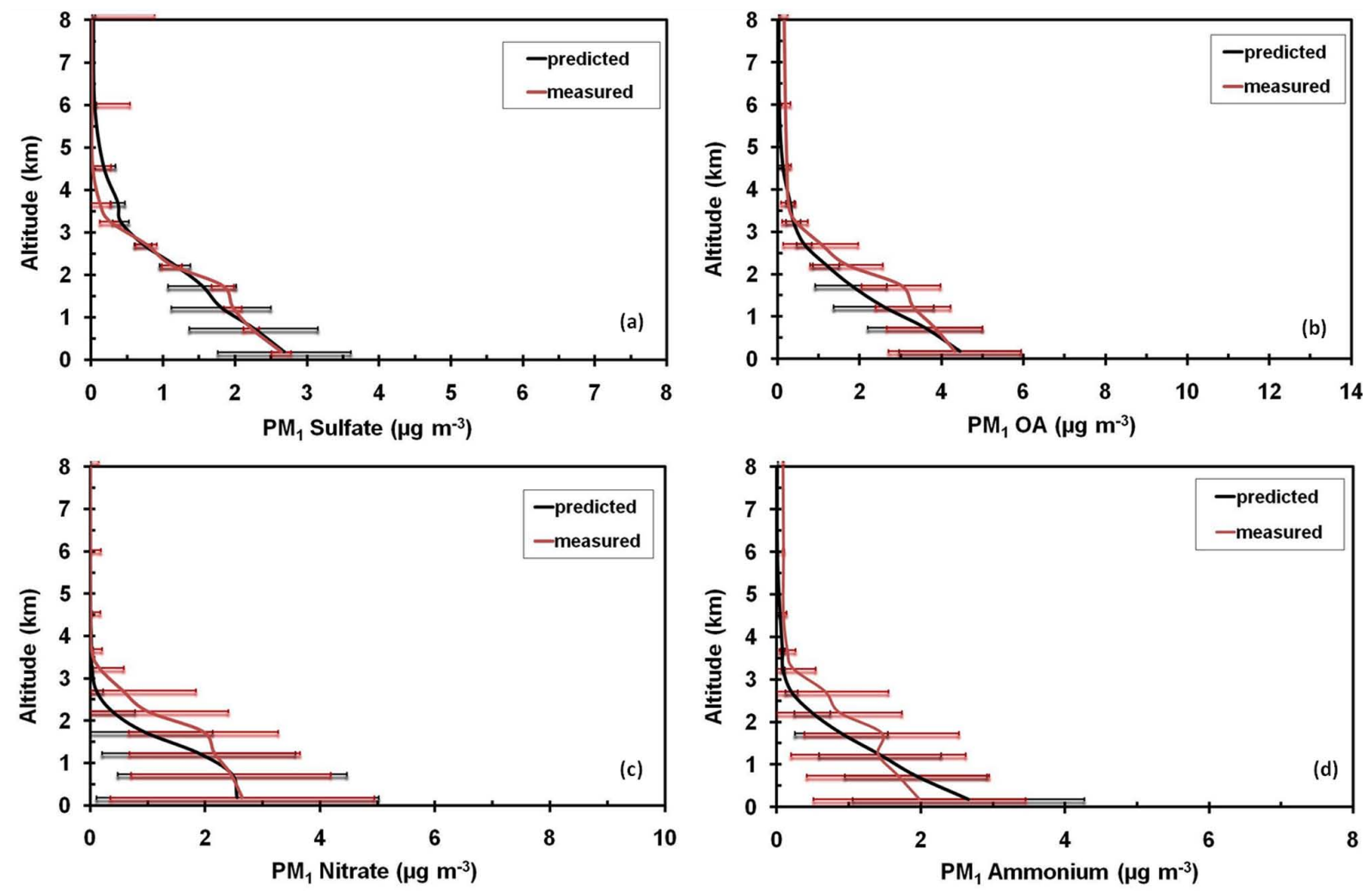

Fig. 8. Comparison of predicted (PMCAMx-2008) vs. observed (AMS) vertical profiles of aerosol chemical composition averaged over the entire EUCAARI-LONGREX campaign for $\mathrm{PM}_{1}$ (a) sulfate, (b) organics, (c) nitrate and (d) ammonium. The horizontal bars indicate one standard deviation for each $500 \mathrm{~m}$ altitude bin mean value.

in organic aerosol, which is predicted to be predominantly composed of oxidized primary OA (including IVOC oxidation) $(55-60 \%)$ and biogenic SOA $(30-35 \%)$. Much of the traditionally thought as particulate primary OA emissions are actually evaporating to produce low-volatility organic vapors which are the source (through photochemical aging) of a substantial amount of oxygenated OA that is distributed not only in urban and suburban areas but rural regions as well. PMCAMx-2008 tends to predict relatively flat diurnal profiles for $\mathrm{PM}_{1} \mathrm{OA}$ in many areas, both rural and urban. Finally, the model reproduces the relatively low OA concentrations in the free troposphere over Europe, suggesting that at least for this period there were no major missing OA sources aloft.

Acknowledgements. This work was funded by the European Commission 6th Framework Programme project EUCAARI (contract 34684). C. Fountoukis was partially supported by a Marie Curie International Reintegration Grant within the 7th European Community Framework Programme. The UK Facility for Airborne Atmospheric Measurements (FAAM) BAe-146 aircraft was supported by NERC ADIENT project NE/E011101/1. We thank W. T. Morgan and H. Coe for provision of the aircraft AMS data. The NERC National Centre for Atmospheric Science (NCAS) Facility for Ground based Atmospheric Measurements (FGAM) supported the maintenance of the cToF-AMS. The authors would like to thank A. Mensah and A. Kiendler-Scharr for providing the measurement data from Cabauw, L. Poulain, G. Spindler, H. Herrmann and W. Birmili for the Melpitz data, L. Hildebrandt and the Carnegie Mellon University and the Paul Scherrer Institute teams for the Finokalia AMS measurements, Mikhail Sofiev for assistance with the fire emission inventory. Chlorofyll- $a$ data used in this study for the emission fields were acquired using the GES-DISC Interactive Online Visualization ANd aNalysis Infrastructure (GIOVANNI) as part of the NASA's Goddard Earth Sciences (GES) Data and Information Services Center (DISC).

Edited by: V.-M. Kerminen

\section{References}

Andersson-Skold, Y. and Simpson, D.: Secondary organic aerosol formation in northern Europe: A model study, J. Geophys. Res., 106, 7357-7374, doi:10.1029/2000JD900656, 2001.

Andreae, M. O. and Crutzen, P. J.: Atmospheric aerosols: biogeochemical sources and role in atmospheric chemistry, Science, 276, 1052-1058, 1997.

Atkinson, R. and Arey, J.: Atmospheric degradation of volatile organic compounds, Chem. Rev., 103, 4605-4638, 2003. 
Baltensperger, U., Kalberer, M., Dommen, J., Paulsen, D., Alfarra, M. R., Coe, H., Fisseha, R., Gascho, A., Gysel, M., Nyeki, S., Sax, M., Steinbacher, M., Prevot, A. S. H., Sjogren, S., Weingartner, E., and Zenobi, R.: Secondary organic aerosols from anthropogenic and biogenic precursors, Faraday Discuss., 130, 265-278, 2005.

Bessagnet, B., Menut, L., Curci, G., Hodzic, A., Guillaume, B., Liousse, C., Moukhtar, S., Pun, B., Seigneur, C., and Schulz, M.: Regional modeling of carbonaceous aerosols over Europe-focus on secondary organic aerosols, J. Atmos. Chem., 61, 175-202, doi:10.1007/s10874-009-9129-2, 2008.

Birmili, W., Schepanski, K., Ansmann, A., Spindler, G., Tegen, I., Wehner, B., Nowak, A., Reimer, E., Mattis, I., Müller, K., Brüggemann, E., Gnauk, T., Herrmann, H., Wiedensohler, A., Althausen, D., Schladitz, A., Tuch, T., and Löschau, G.: A case of extreme particulate matter concentrations over Central Europe caused by dust emitted over the southern Ukraine, Atmos. Chem. Phys., 8, 997-1016, doi:10.5194/acp-8-997-2008, 2008.

Birmili, W., Weinhold, K., Nordmann, S., Wiedensohler, A., Spindler, G., Müller, K., Herrmann, H., Gnauk, T., Pitz, M., Cyrys, J., Flentje, H., Nickel, C., Kuhlbusch, T. A. J., Löschau, G., Haase, D., Meinhardt, F., Schwerin, A., Ries, L., and Wirtz, K.: Atmospheric aerosol measurements in the German Ultrafine Aerosol Network (GUAN): Part 1 - soot and particle number size distributions, Gefahrst. Reinh. Luft, 69, 137-145, 2009.

Bougiatioti, A., Fountoukis, C., Kalivitis, N., Pandis, S. N., Nenes, A., and Mihalopoulos, N.: Cloud condensation nuclei measurements in the marine boundary layer of the Eastern Mediterranean: CCN closure and droplet growth kinetics, Atmos. Chem. Phys., 9, 7053-7066, doi:10.5194/acp-9-7053-2009, 2009.

Burtraw, D., Krupnick, A., Mansur, E., Austin, D., and Farrell, D.: Costs and benefits of reducing air pollutants related to acid rain, Contemporary Economic Policy, 16, 379-400, doi:10.1111/j.1465-7287.1998.tb00527.x, 2007.

Capaldo, K. P., Pilinis, C., and Pandis, S. N.: A computationally efficient hybrid approach for dynamic gas/aerosol transfer in air quality models, Atmos. Environ., 34, 3617-3627, 2000.

Carter, W. P. L.: Programs and Files Implementing the SAPRC99 Mechanism and its Associates Emissions Processing Procedures for Models-3 and Other Regional Models: http://pah.cert. ucr.edu/ $\sim$ carter/SAPRC99.htm, last access: 31 January 2000.

Dall'Osto, M., Ceburnis, D., Martucci, G., Bialek, J., Dupuy, R., Jennings, S. G., Berresheim, H., Wenger, J., Healy, R., Facchini, M. C., Rinaldi, M., Giulianelli, L., Finessi, E., Worsnop, D., Ehn, M., Mikkilä, J., Kulmala, M., and O’Dowd, C. D.: Aerosol properties associated with air masses arriving into the North East Atlantic during the 2008 Mace Head EUCAARI intensive observing period: an overview, Atmos. Chem. Phys., 10, 8413-8435, doi:10.5194/acp-10-8413-2010, 2010.

Donahue, N. M., Robinson, A. L., Stanier, C. O., and Pandis, S. N.: Coupled partitioning, dilution, and chemical aging of semivolatile organics, Environ. Sci. Technol., 40, 2635-2643, 2006.

Dzepina, K., Volkamer, R. M., Madronich, S., Tulet, P., Ulbrich, I. M., Zhang, Q., Cappa, C. D., Ziemann, P. J., and Jimenez, J. L.: Evaluation of recently-proposed secondary organic aerosol models for a case study in Mexico City, Atmos. Chem. Phys., 9, 5681-5709, doi:10.5194/acp-9-5681-2009, 2009.
Engler, C., Rose, D., Wehner, B., Wiedensohler, A., Brggemann, E., Gnauk, T., Spindler, G., Tuch, T., and Birmili, W.: Size distributions of non-volatile particle residuals $(D p<800 \mathrm{~nm})$ at a rural site in Germany and relation to air mass origin, Atmos. Chem. Phys., 7, 5785-5802, doi:10.5194/acp-7-5785-2007, 2007.

ENVIRON: User's Guide to the Comprehensive Air Quality Model with Extensions (CAMx), Version 4.02, Report, ENVIRON Int. Corp., Novato, Calif, available at: http://www.camx.com, 2003.

Fahey, K. and Pandis, S. N.: Optimizing model performance: variable size resolution in cloud chemistry modeling, Atmos. Environ., 35, 4471-4478, 2001.

Farina, S. C., Adams, P. J., and Pandis, S. N.: Modeling global secondary organic aerosol formation and processing with the volatility basis set: Implications for anthropogenic secondary organic aerosol, J. Geophys. Res., 115, D09202, doi:10.1029/2009JD013046, 2010.

Ganor, E., Foner, H. A., Bingemer, H. G., Udisti, R., and Setter, I.: Biogenic sulphate generation in the Mediterranean Sea and its contribution to the sulphate anomaly in the aerosol over Israel and the Eastern Mediterranean, Atmos. Environ., 36, 929-938, 2000.

Gaydos, T., Koo, B., and Pandis, S. N.: Development and application of an efficient moving sectional approach for the solution of the atmospheric aerosol condensation/evaporation equations, Atmos. Environ., 37, 3303-3316, 2003.

Gelencser, A., May, B., Simpson, D., Sanchez-Ochoa, A., Kasper-Giebl, A., Puxbaum, H., Caseiro, A., Pio, C., and Legrand, M.: Source apportionment of PM2.5 organic aerosol over Europe: Primary/secondary, natural/anthropogenic, and fossil/biogenic origin, J. Geophys. Res., 112, D23S04, doi:10.1029/2006JD008094, 2007.

Guenther, A., Karl, T., Harley, P., Wiedinmyer, C., Palmer, P. I., and Geron, C.: Estimates of global terrestrial isoprene emissions using MEGAN (Model of Emissions of Gases and Aerosols from Nature), Atmos. Chem. Phys., 6, 3181-3210, doi:10.5194/acp-63181-2006, 2006.

Heald, C. L., Jacob, D. J., Park, R. J., Russell, L. M., Huebert, B. J., Seinfeld, J. H., Liao, H., and Weber, R. J.: A large organic aerosol source in the free troposphere missing from current models, Geophys. Res. Lett., 32, L18809, doi:10.1029/2005GL023831, 2005.

Helmig, D., Ortega, J., Guenther, A., Herrick, J. D., and Geron, C.: Sesquiterpene emissions from loblolly pine and their potential contribution to biogenic aerosol formation in the Southeastern US, Atmos. Environ., 40, 4150-4157, 2006.

Hildebrandt, L., Donahue, N. M., and Pandis, S. N.: High formation of secondary organic aerosol from the photo-oxidation of toluene, Atmos. Chem. Phys., 9, 2973-2986, doi:10.5194/acp-92973-2009, 2009.

Hildebrandt, L., Engelhart, G. J., Mohr, C., Kostenidou, E., Lanz, V. A., Bougiatioti, A., DeCarlo, P. F., Prevot, A. S. H., Baltensperger, U., Mihalopoulos, N., Donahue, N. M., and Pandis, S. N.: Aged organic aerosol in the Eastern Mediterranean: the Finokalia Aerosol Measurement Experiment - 2008, Atmos. Chem. Phys., 10, 4167-4186, doi:10.5194/acp-10-4167-2010, 2010.

Hodzic, A., Jimenez, J. L., Madronich, S., Canagaratna, M. R., DeCarlo, P. F., Kleinman, L., and Fast, J.: Modeling organic aerosols in a megacity: potential contribution of semi-volatile 
and intermediate volatility primary organic compounds to secondary organic aerosol formation, Atmos. Chem. Phys., 10, 5491-5514, doi:10.5194/acp-10-5491-2010, 2010.

Huffman, J. A., Docherty, K. S., Aiken, A. C., Cubison, M. J., Ulbrich, I. M., DeCarlo, P. F., Sueper, D., Jayne, J. T., Worsnop, D. R., Ziemann, P. J., and Jimenez, J. L.: Chemically-resolved aerosol volatility measurements from two megacity field studies, Atmos. Chem. Phys., 9, 7161-7182, doi:10.5194/acp-9-71612009, 2009a.

Huffman, J. A., Docherty, K. S., Mohr, C., Cubison, M. J., U1brich, I. M., Ziemann, P. J., Onasch, T. B., and Jimenez, J. L.: Chemically-resolved volatility measurements of organic aerosol from different sources, Environ. Sci. Technol., 43, 5351-5357, 2009 b.

Jayne, J. T., Leard, D. C., Zhang, X. F., Davidovits, P., Smith, K. A., Kolb, C. E., and Worsnop, D. R.: Development of an aerosol mass spectrometer for size and composition analysis of submicron particles, Aerosol Sci. Tech., 33, 49-70, 2000.

Jimenez, J. L., Jayne, J. T., Shi, Q., Kolb, C. E., Worsnop, D. R., Yourshaw, I., Seinfeld, J. H., Flagan, R. C., Zhang, X., Smith, K. A., Morris, J., and Davidovits, P.: Ambient aerosol sampling using the Aerodyne Aerosol Mass Spectrometer, J. Geophys. Res., 108, 8425, doi:10.1029/2001JD001213, 2003.

Kanakidou, M., Seinfeld, J. H., Pandis, S. N., Barnes, I., Dentener, F. J., Facchini, M. C., Van Dingenen, R., Ervens, B., Nenes, A., Nielsen, C. J., Swietlicki, E., Putaud, J. P., Balkanski, Y., Fuzzi, S., Horth, J., Moortgat, G. K., Winterhalter, R., Myhre, C. E. L., Tsigaridis, K., Vignati, E., Stephanou, E. G., and Wilson, J.: Organic aerosol and global climate modelling: a review, Atmos. Chem. Phys., 5, 1053-1123, doi:10.5194/acp-5-1053-2005, 2005.

Karydis, V. A., Tsimpidi, A. P., Fountoukis, C., Nenes A., Zavala, M., Lei, W., Molina, L. T., and Pandis, S. N.: Simulating the fine and coarse inorganic particulate matter concentrations in a polluted megacity, Atmos. Environ., 44, 608-620, 2010.

Koo, B., Pandis, S. N., and Ansari, A.: Integrated approaches to modeling the organic and inorganic atmospheric aerosol components, Atmos. Environ., 37, 4757-4768, 2003.

Koulouri, E., Saarikoski, S., Theodosi, C., Markaki, Z., Gerasopoulos, E., Kouvarakis, G., Makela, T., Hillamo, R., and Mihalopoulos, N.: Chemical composition and sources of fine and coarse aerosol particles in the Eastern Mediterranean, Atmos. Environ., 42, 6542-6550, doi:10.1016/j.atmosenv.2008.04.010, 2008.

Kulmala, M., Asmi, A., Lappalainen, H. K., Carslaw, K. S., Pöschl, U., Baltensperger, U., Hov, Ø., Brenquier, J.-L., Pandis, S. N., Facchini, M. C., Hansson, H.-C., Wiedensohler, A., and O'Dowd, C. D.: Introduction: European Integrated Project on Aerosol Cloud Climate and Air Quality interactions (EUCAARI) - integrating aerosol research from nano to global scales, Atmos. Chem. Phys., 9, 2825-2841, doi:10.5194/acp-9-2825-2009, 2009.

Kumar, N., Lurmann, F. W., Wexler, A. S., Pandis, S. N., and Seinfeld, J. H.: Development and Application of a Three Dimensional Aerosol Model. Presented at the A\&WMA Specialty Conference on Computing in Environmental Resource Management, Research Triangle Park, NC, 2-4 December 1996.

Lane, T. E., Donahue, N. M., and Pandis, S. N.: Simulating secondary organic aerosol formation using the volatility basis-set approach in a chemical transport model, Atmos. Environ., 42,
7439-7451, 2008a.

Lane, T. E., Donahue, N. M., and Pandis, S. N.: Effect of $\mathrm{NO}_{\mathrm{x}}$ on secondary organic aerosol concentrations, Environ. Sci. Technol., 42, 6022-6027, 2008b.

Lelieveld, J., Berresheim, H., Borrmann, S., Crutzen, P. J., Dentener, F. J., Fischer, H., Feichter, J., Flatau, P. J., Heland, J., Holzinger, R., Korrmann, R., Lawrence, M. G., Levin, Z., Markowicz, K. M., Mihalopoulos, N., Minikin, A., Ramanathan, V., de Reus, M., Roelofs, G., J., Scheeren, H. A., Sciare, J., Schlager, H., Schultz, M., Siegmund, P., Steil, B., Stephanou, E. G., Stier, P., Traub, M., Warneke, C., Williams, J., and Ziereis, H.: Global Air Pollution Crossroads over the Mediterranean, Science, 298, 794-799, doi:10.1126/science.1075457, 2002.

Lipsky, E. M. and Robinson, A. L.: Effects of dilution on fine particle mass and partitioning of semivolatile organics in diesel exhaust and wood smoke, Environ. Sci. Technol., 40, 155-162, 2006.

Mihalopoulos, N., Stephanou, E., Kanakidou, M., Pilitsidis, S., and Bousquet, P.: Tropospheric aerosol ionic composition in the Eastern Mediterranean region, Tellus B, 49, 314-326, 1997.

Morgan, W. T., Allan, J. D., Bower, K. N., Esselborn, M., Harris, B., Henzing, J. S., Highwood, E. J., Kiendler-Scharr, A., McMeeking, G. R., Mensah, A. A., Northway, M. J., Osborne, S., Williams, P. I., Krejci, R., and Coe, H.: Enhancement of the aerosol direct radiative effect by semi-volatile aerosol components: airborne measurements in North-Western Europe, Atmos. Chem. Phys., 10, 8151-8171, doi:10.5194/acp-10-8151-2010, 2010a.

Morgan, W. T., Allan, J. D., Bower, K. N., Highwood, E. J., Liu, D., McMeeking, G. R., Northway, M. J., Williams, P. I., Krejci, R., and Coe, H.: Airborne measurements of the spatial distribution of aerosol chemical composition across Europe and evolution of the organic fraction, Atmos. Chem. Phys., 10, 4065-4083, doi:10.5194/acp-10-4065-2010, 2010b.

Murphy, B. N. and Pandis, S. N.: Simulating the formation of semivolatile primary and secondary organic aerosol in a regional chemical transport model, Environ. Sci. Technol., 43, 47224728, 2009.

Murphy, B. N., Donahue, N. M., Fountoukis, C., and Pandis, S. N.: Simulating the oxygen content of ambient organic aerosol with the 2D volatility basis set, Atmos. Chem. Phys., 11, 7859-7873, doi:10.5194/acp-11-7859-2011, 2011.

Nenes, A., Pandis, S. N., and Pilinis, C.: ISORROPIA: a new thermodynamic equilibrium model for multiphase multicomponent inorganic aerosols, Aquat. Geochem., 4, 123-152, 1998.

Ng, N. L., Kroll, J. H., Keywood, M. D., Bahreini, R., Varutbangkul, V., Flagan, R. C., and Seinfeld, J. H.: Contribution of first- versus second-generation products to secondary organic aerosols formed in the oxidation of biogenic hydrocarbons, Environ. Sci. Technol., 40, 2283-2297, 2006.

O’Dowd, C. D., Langmann, B., Varghese, S., Scannell, C., Ceburnis, D., and Facchini, M. C.: A Combined Organic-Inorganic Sea-Spray Source Function, Geophys. Res. Lett., 35, L01801, doi:10.1029/2007GL030331, 2008.

Pandis, S. N., Wexler, A. S., and Seinfeld, J. H.: Secondary organic aerosol formation and transport. 2. Predicting the ambient secondary organic aerosol size distribution, Atmos. Environ., 27A, 2403-2416, 1993. 
Pikridas, M., Bougiatioti, A., Hildebrandt, L., Engelhart, G. J., Kostenidou, E., Mohr, C., Prévôt, A. S. H., Kouvarakis, G., Zarmpas, P., Burkhart, J. F., Lee, B.-H., Psichoudaki, M., Mihalopoulos, N., Pilinis, C., Stohl, A., Baltensperger, U., Kulmala, M., and Pandis, S. N.: The Finokalia Aerosol Measurement Experiment - 2008 (FAME-08): an overview, Atmos. Chem. Phys., 10, 6793-6806, doi:10.5194/acp-10-6793-2010, 2010.

Pilinis, C., Capaldo, K. P., Nenes, A., and Pandis, S. N.: MADM - a new multicomponent aerosol dynamics model. Aerosol Science and Technology, 32, 482-502, 2000.

Pope, C. A., Burnett, R. T., Thun, M. J., Calle, E. E., Krewski, D., Ito, K., and Thurston, G. D.: Lung cancer, cardiopulmonary mortality, and long-term exposure to fine particulate air pollution, Journal of the American Medical Association, 287, 1132-1141, 2002.

Pun, B. K., Wu, S. Y., Seigneur, C., Seinfeld, J. H., Griffin, R. J., and Pandis, S. N.: Uncertainties in modeling secondary organic aerosols: Three-dimensional modeling studies in Nashville/Western Tennessee, Environ. Sci. Technol., 37, 36473661, doi:10.1021/es0341541, 2003.

Roberts, G. C., Andreae, M. O., Zhou, J., and Artaxo, P.: Cloud condensation nuclei in the Amazon Basin: "Marine" conditions over a continent?, Geophys. Res. Lett., 28, 2807-2810, 2001.

Robinson, A. L., Donahue, N. M., Shrivastava, M. K., Weitkamp, E. A., Sage, A. M., Grieshop, A. P., Lane, T. E., Pierce, J. R., and Pandis, S. N.: Rethinking organic aerosol: semivolatile emissions and photochemical aging, Science, 315, 1259-1262, 2007.

Schell, B., Ackermann, I. J., Hass, H., Binkowski, F. S., and Ebel, A.: Modeling the formation of secondary organic aerosol within a comprehensive air quality model system, J. Geophys. Res., 106, 28275-28293, doi:10.1029/2001JD000384, 2001.

Schwartz, J.: Air pollution and hospital admissions for respiratory disease, Epidemiology, 7, 20-28, 1996.

Sciare, J., Bardouki, H., Moulin, C., and Mihalopoulos, N.: Aerosol sources and their contribution to the chemical composition of aerosols in the Eastern Mediterranean Sea during summertime, Atmos. Chem. Phys., 3, 291-302, doi:10.5194/acp-3-291-2003, 2003.

Seinfeld, J. H. and Pandis, S. N.: Atmospheric chemistry and physics: From air pollution to climate change. 2nd ed.; John Wiley and Sons, Hoboken, NJ, 2006.

Shrivastava, M. K., Lane, T. E., Donahue, N. M., Pandis, S. N., and Robinson, A. L.: Effects of gas-particle partitioning and aging of primary emissions on urban and regional organic aerosol concentrations, J. Geophys. Res., 113, D18301, doi:10.1029/2007JD009735, 2008.

Simpson, D. Yttri, K. E., Klimont, Z., Kupiainen, K., Caseiro, A., Gelencser, A., Pio, C., Puxbaum, H., and Legrand, M.: Modeling carbonaceous aerosol over Europe: Analysis of the CARBOSOL and EMEP EC/OC campaigns, J. Geophys. Res., 112, D23S14, doi:10.1029/2006JD008158, 2007.

Skamarock, W. C., Klemp, J. B., Dudhia, J., Gill, D. O., Barker, D. M., Wang, W., and Powers, J. G.: A Description of the Advanced Research WRF Version 2, NCAR Technical Note (http://www. mmm.ucar.edu/wrf/users/docs/arw_v2.pdf), 2005.

Slinn, S. A. and Slinn, W. G. N.: Predictions for particle deposition on natural waters. Atmos. Environ., 24, 1013-1016, 1980.
Sofiev, M., Vankevich, R., Lanne, M., Koskinen, J., and Kukkonen, J.: On integration of a Fire Assimilation System and a chemical transport model for near-real-time monitoring of the impact of wild-land fires on atmospheric composition and air quality, Modelling, Monitoring and Management of Forest Fires, WIT Transactions on Ecology and the Environment, 119, 343-351, 2008 a.

Sofiev, M., Lanne, M., Vankevich, R., Prank, M., Karppinen, A., and Kukkonen, J.: Impact of wild-land fires on European air quality in 2006-2008, Modelling, Monitoring and Management of Forest Fires, WIT Transactions on Ecology and the Environment, 119, 353-361, 2008b.

Spindler, G., Brüggemann, E., Gnauk, T., Grüner, A., Müller, K., and Herrmann, H.: A four-year size-segregated characterization study of particles $\mathrm{PM}_{10}, \mathrm{PM}_{2.5}$ and $\mathrm{PM}_{1}$ depending on air mass origin at Melpitz. Atmos. Environ., 44, 164-173, 2010.

Stanier, C. O., Donahue, N. M., and Pandis, S. N.: Parameterization of secondary organic aerosol mass fraction from smog chamber data, Atmos. Environ., 42, 2276-2299, 2008.

Szidat, S., Jenk, T. M., Synal, H. A., Kalberer, M., Wacker, L., Hajdas, I., Kasper-Giebl, A., and Baltensperger, U.: Contributions of fossil fuel, biomass-burning, and biogenic emissions to carbonaceous aerosols in Zurich as traced by (14)C, J. Geophys. Res., 111, D07206, doi:10.1029/2005JD006590, 2006.

Takegawa, N., Miyazaki, Y., Kondo, Y., Komazaki, Y., Miyakawa, T., Jimenez, J. L., Jayne, J. T., Worsnop, D. R., Allan, J. D., and Weber, R. J.: Characterization of an Aerodyne Aerosol Mass Spectrometer (AMS): Intercomparison with other aerosol instruments, Aerosol Sci. Tech., 39, 760-770, 2005.

Tsigaridis, K. and Kanakidou, M.: Global modelling of secondary organic aerosol in the troposphere: a sensitivity analysis, Atmos. Chem. Phys., 3, 1849-1869, doi:10.5194/acp-3-1849-2003, 2003.

Tsimpidi, A. P., Karydis, V. A., Zavala, M., Lei, W., Molina, L., Ulbrich, I. M., Jimenez, J. L., and Pandis, S. N.: Evaluation of the volatility basis-set approach for the simulation of organic aerosol formation in the Mexico City metropolitan area, Atmos. Chem. Phys., 10, 525-546, doi:10.5194/acp-10-525-2010, 2010.

Tsimpidi, A. P., Karydis, V. A., Zavala, M., Lei, W., Bei, N., Molina, L., and Pandis, S. N.: Sources and production of organic aerosol in Mexico City: insights from the combination of a chemical transport model (PMCAMx-2008) and measurements during MILAGRO, Atmos. Chem. Phys., 11, 5153-5168, doi:10.5194/acp-11-5153-2011, 2011.

Tunved, P., Hansson, H. C., Kerminen, V. M., Strom, J., Dal Maso, M., Lihavainen, H., Viisanen, Y., Aalto, P. P., Komppula, M., and Kulmala, M.: High natural aerosol loading over boreal forests, Science, 312, 5771, 261-263, doi:10.1126/science.1123052, 2006.

Visschedijk, A. J. H., Zandveld, P., and Denier van der Gon, H. A. C.: TNO Report 2007 A-R0233/B: A high resolution gridded European emission database for the EU integrated project GEMS, Netherlands, Organization for Applied Scientific Research, 2007.

Wesely, M. L.: Parameterization of Surface Resistances to Gaseous Dry Deposition in Regional-Scale Numerical Models. Atmos. Environ., 23, 1293-1304, 1989. 
Zhang, Q., Canagaratna, M. C., Jayne, J. T., Worsnop, D. R., and Jimenez, J. L: Time and size-resolved chemical composition of submicron particles in Pittsburgh Implications for aerosol sources and processes, J. Geophys. Res., 110, D07S09, doi:10.1029/2004JD004649, 2005a.

Zhang, Q., Worsnop, D. R., Canagaratna, M. R., and Jimenez, J. L.: Hydrocarbon-like and oxygenated organic aerosols in Pittsburgh: insights into sources and processes of organic aerosols, Atmos. Chem. Phys., 5, 3289-3311, doi:10.5194/acp-5-32892005, 2005b.
Zhang, Q., Jimenez, J. L., Canagaratna, M. R., Allan, J. D., Coe, H., Ulbrich, I., Alfarra, M. R., Takami, A., Middlebrook, A. M., Sun, Y. L., Dzepina, K., Dunlea, E., Docherty, K., De-Carlo, P., Salcedo, D., Onasch, T. B., Jayne, J. T., Miyoshi, T., Shimono, A., Hatakeyama, N., Takegawa, N., Kondo, Y., Schneider, J., Drewnick, F., Weimer, S., Demerjian, K. L., Williams, P. I., Bower, K. N., Bahreini, R., Cottrell, L., Griffin, R. J., Rautianen, J., and Worsnop, D. R.: Ubiquity and dominance of oxygenated species in organic aerosols in anthropogenicallyinfluenced Northern Hemisphere midlatitudes, Geophys. Res. Lett., 34, L13801, doi:10.1029/2007GL029979, 2007. 